\title{
Bioactivity, Health Benefits, and Related Molecular Mechanisms of Curcumin: Current Progress, Challenges, and Perspectives
}

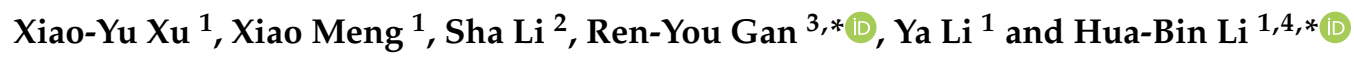 \\ 1 Department of Nutrition, School of Public Health, Sun Yat-Sen University, Guangzhou 510080, China; \\ xuxy53@mail2.sysu.edu.cn (X.-Y.X.); mengx7@mail2.sysu.edu.cn (X.M.); liya28@mail3.sysu.edu.cn (Y.L.) \\ 2 School of Chinese Medicine, Li Ka Shing Faculty of Medicine, The University of Hong Kong, \\ Hong Kong 999077, China; u3003781@connect.hku.hk \\ 3 Department of Food Science \& Technology, School of Agriculture and Biology, Shanghai Jiao Tong \\ University, Shanghai 200240, China \\ 4 South China Sea Bioresource Exploitation and Utilization Collaborative Innovation Center, Sun Yat-Sen \\ University, Guangzhou 510006, China \\ * Correspondence: renyougan@sjtu.edu.cn (R.-Y.G.); lihuabin@mail.sysu.edu.cn (H.-B.L.); \\ Tel.: +86-21-34208517 (R.-Y.G.); +86-20-87332391 (H.-B.L.)
}

Received: 27 August 2018; Accepted: 16 October 2018; Published: 19 October 2018

\begin{abstract}
Curcumin is a principal curcuminoid of turmeric (Curcuma longa), which is commonly used as a spice in cooking and a yellow pigment in the food processing industry. Recent studies have demonstrated that curcumin has a variety of biological activities and pharmacological performances, providing protection and promotion of human health. In addition to presenting an overview of the gut metabolism of curcumin, this paper reviews the current research progress on its versatile bioactivity, such as antioxidant, anti-inflammatory, and immune-regulatory activities, and also intensively discusses its health benefits, including the protective or preventive effects on cancers and diabetes, as well as the liver, nervous system, and cardiovascular systems, highlighting the potential molecular mechanisms. Besides, the beneficial effects of curcumin on human are further stated based on clinical trials. Considering that there is still a debate on the beneficial effects of curcumin, we also discuss related challenges and prospects. Overall, curcumin is a promising ingredient of novel functional foods, with protective efficacy in preventing certain diseases. We hope this comprehensive and updated review will be helpful for promoting human-based studies to facilitate its use in human health and diseases in the future.
\end{abstract}

Keywords: curcumin; gut metabolism; health benefits; antioxidant; anticancer; anti-inflammatory; molecular mechanisms

\section{Introduction}

Turmeric, the powdered rhizome of Curcuma longa, is a member of the Zingiberaceae family [1]. The extract of turmeric contains three major curcuminoids (Figure 1): Curcumin (60-70\%), demethoxycurcumin (20-27\%), and bisdemethoxycurcumin (10-15\%) [2]. Curcumin ((1E,6E)-1,7bis(4-hydroxy-3-methoxyphenyl)-1,6-heptadiene-3,5-dione) has two aromatic O-methoxy phenolic groups, a $\beta$-dicarbonyl moiety and a seven-carbon linker containing two enone moieties. Structural modifications with different functional groups have improved the physicochemical and bioactive properties of curcumin [3]. There have been numerous studies on the bioactivity and health benefits of curcumin, such as antioxidant, anti-inflammatory, immune regulatory, anticancer, antidiabetic, neuro-protective, cardiovascular protective, and hepatoprotective effects $[4,5]$. To better understand 
the beneficial effects of curcumin on health, we conducted a search for relevant articles in the Institute of Science Information (ISI) Web of Science core collection and PubMed from 2013 to the present. In this review, we first state the metabolic pathways of curcumin in the intestine, followed by summarizing its diverse bioactivity and health benefits, and also discuss related molecular mechanisms. Therefore, we hope this updated review can provide a better understanding of the beneficial effects of curcumin.

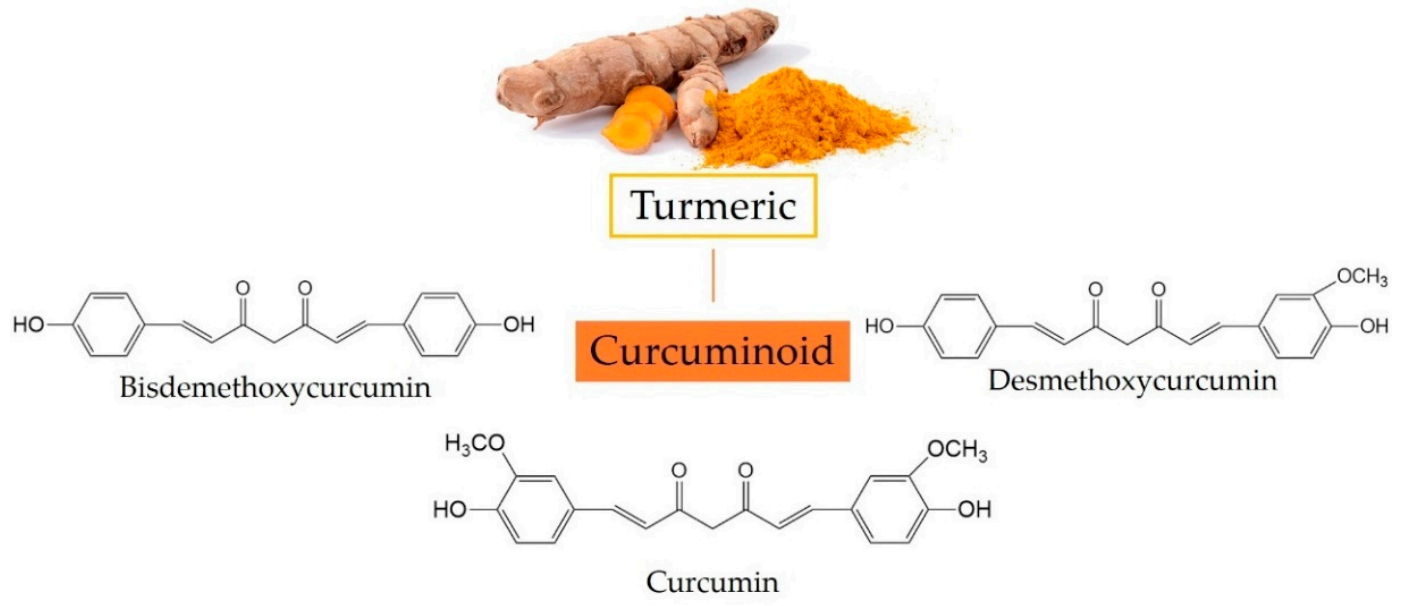

Figure 1. Three major curcuminoids in turmeric and their chemical structures.

\section{The Metabolism of Curcumin}

The metabolism of curcumin is critical for its potent biological activities as well as the beneficial effects on health [6]. In the mammalian body, curcumin can be presented in three major forms, which are free, conjugated, and reduced states [7-9] (Figure 2). Oral administration mainly metabolizes curcumin into the conjugated curcumin via glucuronidation and sulfation. Especially, the finding demonstrates that the gastrointestinal tract plays an important role in the glucuronidation of curcuminoids in human [10]. In addition, intravenous or intraperitoneal administration leads to the reduction of curcumin into dihydrocurcumin, tetrahydrocurcumin, and hexahydrocurcumin [11]. However, minor free and intact curcumin can be detected in plasma after the administration [12]. On the other hand, the metabolism of curcuminoids mainly leads to reductive metabolites, for example, hexahydrocurcuminoids are the major reductive metabolites observed in both male and female rat liver [13].

Due to the low chemical stability and poor bioavailability of curcumin, more attention has been paid to its metabolites [14]. Although the major structure of its metabolites is consistent with curcumin, the minor differences in the structure of metabolites improve their chemical stability. For example, the hexahydrocurcumin has the same phenolic groups or diketo moieties as curcumin, but has no olefinic double bonds, leading to hexahydrocurcumin being more stable than curcumin at a physiological pH of 7.4 [15]. In the intestine, the absorption of curcumin is poor, while the reductive and conjugated curcumin metabolites show moderate absorption [16]. Hence, it is hypothesized that the biological effects of curcumin in tissues, such as liver and kidney, may be attributed to the curcumin metabolites [17]. However, the metabolism or degradation of curcumin can affect the bioactivity of curcumin. A finding shows that curcumin induces arrest in the $G_{2} / M$ phase and mitotic catastrophe in three human cancer cell lines, while the reductive metabolism and chemical degradation inactivate the ability of curcumin to cause cancer cell death [18].

The relationship between curcumin and microbiota plays an important role in the gastrointestinal metabolism of curcumin [19]. The main metabolic process in human intestinal microbiota includes demethoxylation, reduction, hydroxylation, methylation, and acetylation [20]. A study used the bacteria strain, Bacillus megaterium DCMB-002, isolated from mice feces to treat with curcumin, and the bacteria have been found to transform curcumin into various metabolites [21]. In addition, the human 
intestinal bacteria, Blautia sp. MRG-PMF1, have been reported to biotransform curcumin via the methyl aryl ether cleavage reaction [22].

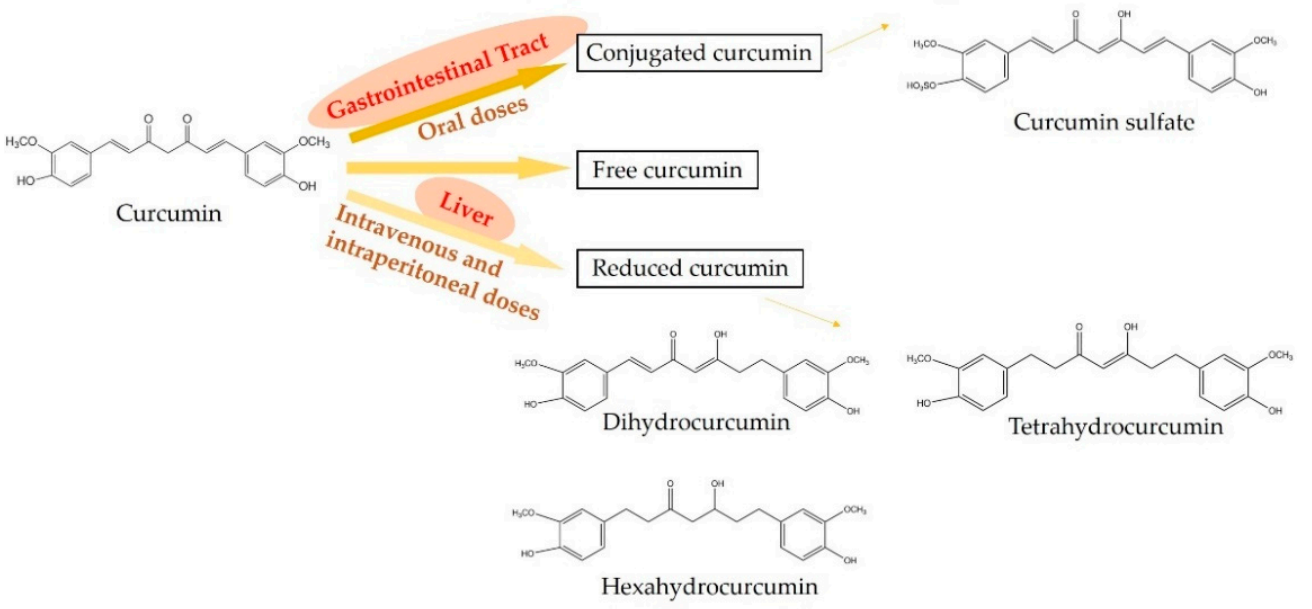

Figure 2. Metabolic pathways of curcumin. Oral administration mainly metabolizes curcumin into conjugated curcumin, while intravenous or intraperitoneal administration mainly leads to reduced curcumin. In addition, minor free and intact curcumin can be detected in plasma after any administration.

\section{Bioactivity of Curcumin}

\subsection{Antioxidant Activity}

The imbalance between free radicals and the body's defense system against oxidative stress can cause various chronic diseases [23]. An excessive production of reactive oxygen species (ROS) can induce oxidative stress and damage essential biomolecules, while antioxidants, including antioxidant enzymes and antioxidant compounds, can protect the human body from free radicals and ROS effects, attenuating the progress of many chronic diseases [24]. Both in vitro and in vivo studies have revealed the antioxidant activity of curcumin contributes to its diverse therapeutic effects. The research on the chemical structure of curcumin shows that electron-donating groups of curcumin, especially the phenolic hydroxyl group, are the main contributors to its antioxidant activity [25].

Curcumin mainly reduces the oxidative stress by scavenging free radicals [26]. Studies have shown that curcumin can directly remove the excessive free radicals and prevent ROS production [27]. In A549 cells with influenza A virus (IAV)-induced oxidant stress, curcumin treatment is found to inhibit the production of ROS as well as the activation of toll-like receptor (TLR), which may be responsible for the suppression of influenza A virus infection [28]. Quinocetone causes genotoxicity and oxidative stress in human hepatocyte L02 cells, and curcumin pretreatment markedly inhibits excessive ROS generation, with the suppression of the decrease in the activity of antioxidant enzymes, like superoxide dismutase (SOD), and levels of antioxidant constituents, such as glutathione (GSH) [29]. In addition, in diabetic mice, curcumin treatment inhibits ROS production and hyperglycemia-induced oxidative stress by restoring the functions of DNA methyltransferase (DNMT) [30].

On the other hand, curcumin can also increase the activities of antioxidant enzymes. Treatment of curcumin significantly increases the activity of paraoxonase 1 arylesterase (PON1), reduces the susceptibility of low-density lipoprotein (LDL) oxidation, and restores the abnormal biochemical parameters caused by $\mathrm{HgCl}_{2}$ [31,32]. Additionally, the administration of curcumin results in amelioration of aflatoxin B1-induced effects via increases in the level of GSH, gene expression, and 
activities of antioxidant enzymes, such as catalase (CAT), SOD, glutathione peroxidase (GSH-Px), and glutathione-S-transferase (GST) [33]. Furthermore, curcumin significantly reverses the decreased activity of SOD induced by zymosan and attenuates the increase of the level of malondialdehyde (MDA) [34]. In allergic rhinitis, the curcumin fed rats show higher tissue GSH levels in inferior turbinate tissues and GSH-Px activity in serum than those of the control [35]. In addition, curcumin increases the GSH level in erythrocytes and plasma, while simultaneously decreases the oxidant potential of plasma [36]. Furthermore, an in vitro study indicates that curcumin blocks nuclear factor $\mathrm{kB}(\mathrm{NF}-\mathrm{kB})$ activation due to its antioxidant activity [37].

Considering the potent antioxidant activity, curcumin has been found to scavenge free radicals, restore abnormal alternations induced by external factors, and repress transcription factors related to oxidation. These effects help reduce oxidative stress and lower the risk of various chronic diseases. However, it should be pointed out that a compound with antioxidant activity in vitro cannot represent an effective antioxidant in vivo, and it can be a pro-oxidant under certain conditions, showing no health benefits [38].

\subsection{Anti-Inflammatory Activity}

Chronic inflammation is caused by many external or intrinsic factors, and it is considered a key mediator for diseases. Curcumin can not only reduce the oxidative stress, but also protect against inflammation effectively via modulating pro-inflammatory cytokines and related signaling pathways, such as NF- $\mathrm{kB}$, peroxisome proliferator-activated receptor-gamma (PPAR- $\gamma$ ), and myeloid differentiation protein 2-TLR 4 co-receptor (TLR4-MD2) signaling pathways [39-42].

\subsubsection{Regulation of Pro-Inflammatory and Anti-Inflammatory Cytokines}

The inflammatory response is often accompanied by the excessive production of pro-inflammatory cytokines, such as interleukin- 6 (IL-6), tumor necrosis factor- $\alpha$ (TNF- $\alpha$ ), and interleukin-1 $\beta$ (IL-1 $\beta$ ). Therefore, the downregulation of proinflammatory cytokines may effectively reduce the incidence of inflammation [43]. Pretreatment of curcumin on human genital epithelial cells abrogates the glycoprotein 120-mediated upregulation of the pro-inflammatory cytokines, TNF- $\alpha$, and IL-6, as well as the chemokines, IL-8, RANTES (regulated on activation, normal T cell expressed, and secreted), and interferon $\gamma$-induced protein-10 (IP-10) [44]. Moreover, curcumin-loaded solid lipid nanoparticles can effectively decrease the expression of serum pro-inflammatory cytokines, including IL-6, TNF- $\alpha$, and IL-1 $\beta$ [39]. Also, the liposomal curcumin complex effectively decreases pro-inflammatory cytokine and chemokine expression in synovial fibroblasts and macrophages without affecting cell viability, showing less toxicity compared to free curcumin [45]. The degradation product of curcumin, 4-vinyl guaiacol, has been reported to decrease IL-6 gene expression in lipopolysaccharide (LPS)-stimulated murine macrophages [46].

The upregulation of anti-inflammatory cytokines is also essential for the reduction of the inflammatory response. Results show that curcumin can inhibit inflammation and increase M2-like macrophages in white adipose tissues, promoting the production of anti-inflammatory cytokines [47]. Moreover, the in vivo study reveals that curcumin exhibits antiepileptogenic effects by upregulating the gene expression of anti-inflammatory cytokines, such as interleukin 10 receptor (IL-10R), chemokine (C-X-C motif) ligand 16 (CXCL16), and CXCL17 [48]. In cultured macrophages, it is observed that macrophages uptake the curcumin-loaded nanoparticles, and significantly increase the release of anti-inflammatory factors, including transforming growth factor-beta (TGF- $\beta$ ) and IL-10 [49]. To sum up, curcumin exhibits anti-inflammatory activity via the regulation of pro-inflammatory cytokines, such as IL-6, TNF- $\alpha$, and IL- $1 \beta$, as well as anti-inflammatory cytokines, such as IL-10 and TGF- $\beta$.

\subsubsection{Regulating Signaling Pathways Associated with Inflammation}

Nuclear factor $\mathrm{kB}(\mathrm{NF}-\mathrm{kB})$ is a critical inflammatory mediator that controls cytokine production and cell survival. Under the normal condition, NF- $\mathrm{KB}$ is in an inactive state by binding to an inhibitor of 
NF- $\mathrm{kB}(\mathrm{I} \kappa \mathrm{B})$ in the cytoplasm of most cells. Many inflammatory mediators, such as pro-inflammatory cytokines, chemokines, and leukocyte adhesion molecules, are upregulated during inflammation, and can activate NF- $\mathrm{KB}$, which then translocates to the nucleus [50]. Curcumin has been found to exhibit anti-inflammatory activity by suppressing the NF- $\mathrm{kB}$ signaling pathway. A study shows that curcumin treatment maintains the $S$-nitrosylation of the inhibitor of NF-KB kinase subunit $\beta$ (IKK $\beta$, an activating kinase upstream of NF- $k B$ ) in dextran sulfate sodium-induced colitis. Sequentially, curcumin represses the phosphorylation of I $\mathrm{KB}$ and the activation of NF-KB [51]. In addition, pretreatment with curcumin shows an anti-inflammatory effect against the colistin-induced toxicity in neuroblastoma-2a cells, as it significantly downregulates the expression of the pro-inflammatory mediator cyclooxygenase-2 (COX-2), blocks the phosphorylation of IKB, and concomitantly decreases the NF- $\kappa B$ level [52]. Furthermore, the complex of polyethylene glycol (PEG) and curcumin inhibits NF-kB p65 nuclear translocation and c-Jun phosphorylation, and activation of nuclear factor (erythroid-derived 2)-like 2 (Nrf2), interfering with multiple targets involved in the inflammatory response [53]. Curcumin derivatives containing nonsteroidal anti-inflammatory components have been found to block the phosphorylation of IKB- $\alpha$ and suppress the activation of p65 and IкB- $\alpha$ [54]. The diarylpentadienone derivatives of curcumin inhibit LPS-induced inducible nitric oxide synthase (iNOS) expression, and slightly reduces the activation of p65 in nuclei [55]. Furthermore, curcumin analogs with different substitution groups decrease the expression of iNOS and COX-2, and inhibit NF- $\mathrm{kB}$ signaling in macrhahahophages [56].

The anti-inflammatory property of curcumin is also involved in other signaling pathways. Curcumin is also found to induce degranulation in human neutrophils by increasing the cell surface expression of cluster of differentiation 35 (CD35) (secretory vesicle), CD63 (azurophilic granules), and CD66b (gelatinase granules) [40]. The control of neutrophils may be a potential anti-inflammatory mechanism of curcumin. In addition, curcumin exhibits anti-inflammatory activity via the PPAR- $\gamma$. A study finds that curcumin decreases the production of $\mathrm{NO}$ and suppresses the proliferation of vascular smooth muscle cells by elevating PPAR- $\gamma$ activity, so as to attenuate angiotensin II-induced inflammatory responses [41]. Additionally, it has been reported that the TLR4-MD2 signaling complex is inhibited by curcumin and its analogs. It is supposed that curcumin and its analogs can compete with LPS for binding on MD2 and finally reduce the inflammation [42]. Overall, curcumin also exhibits anti-inflammatory activity by interacting with inflammation-related signaling pathways, such as NF- $\mathrm{BB}$, PPAR- $\gamma$, and TLR4-MD2 signaling pathways (Figure 3).

\subsection{Immune-Regulatory Activity}

Numerous studies have indicated that curcumin is beneficial to the immune system, and it interacts with immune cells to protect against immune-related diseases by modulating various immune cells, such as various T lymphocyte subsets, macrophages, dendritic cells, B lymphocytes, and natural killer cells, and improving the aberrant alternations of immunological parameters [57]. 


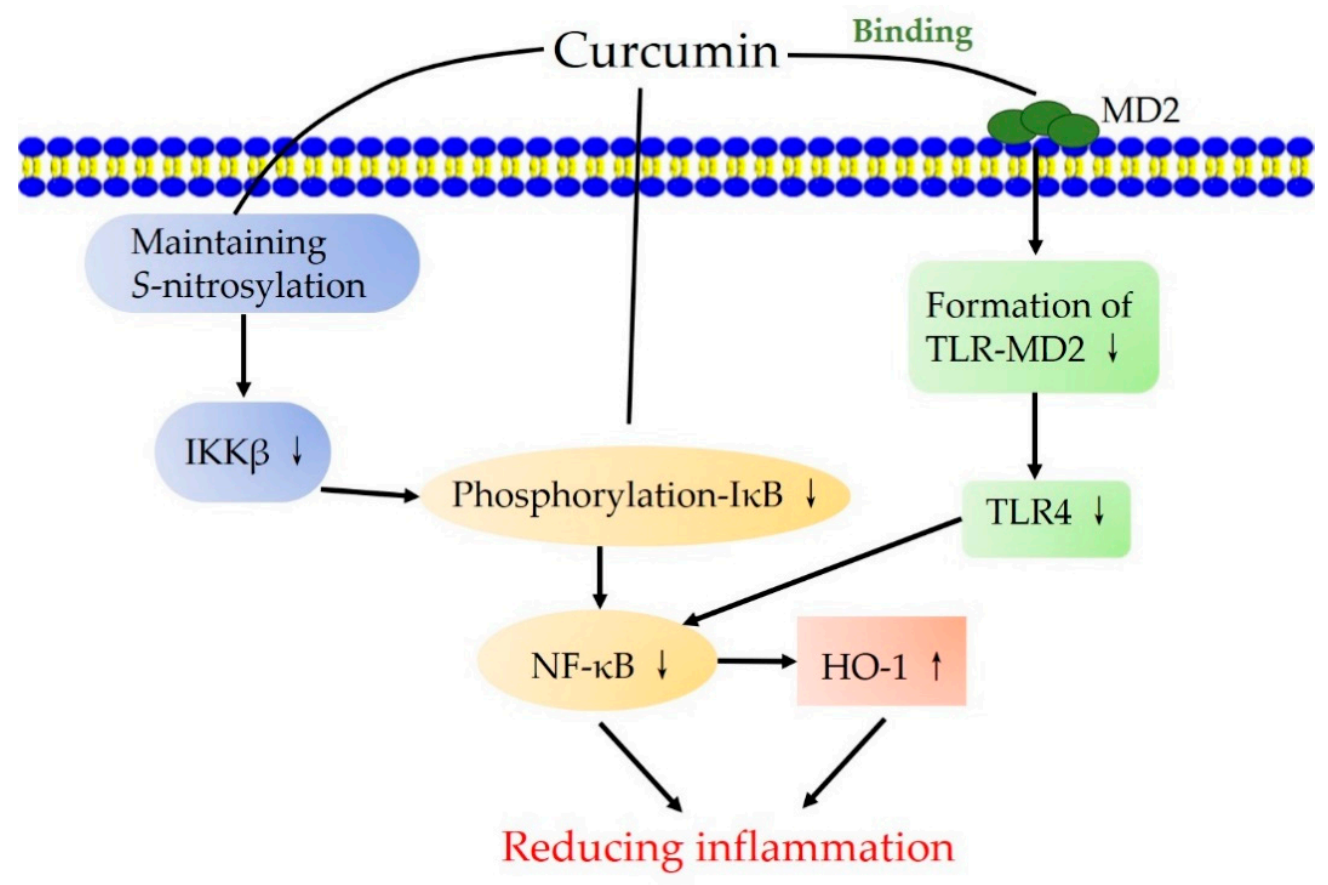

Figure 3. The signaling pathways involved in the anti-inflammation action of curcumin. The up arrows indicate the activation, while the down arrows indicate the inhibition. The treatment with curcumin induces the protection of S-nitrosylation on IKK $\beta$, phosphorylation-I $\kappa \mathrm{B}$, and binding with MD2. The suppression of NF- $\kappa B$ activation and the increase of $\mathrm{HO}-1$ activity contribute to the reduction of inflammation. HO-1, Heme oxygenase-1; IKK $\beta$, Inhibitor of NF- $\kappa B$ kinase subunit $\beta$; I $\kappa B$, Inhibitor of NF-kB; MD2, Myeloid differentiation protein 2; NF-кB, Nuclear factor кB; TLR4, Toll-like receptor 4; TLR4-MD2, Myeloid differentiation protein 2-TLR 4 co-receptor.

Curcumin can reduce the numbers of neutrophil and eosinophil, and increase the lymphocyte counts [58]. In addition, Th1 cells produce IFN- $\gamma$, TNF- $\alpha$, and IL- $1 \beta$, while Th 2 cells produce IL- 4 , IL-10, and TGF- $\beta$. Th17 cells can produce IL-17, and the immune suppressive Treg cells can prevent autoimmune disease. The balance of this subpopulation of $\mathrm{T}$ cells is crucial for the modulation of the immune system [59]. Meanwhile, pro-inflammatory M1 macrophages and anti-inflammatory M2 macrophages correspond to Th1 and Th2 cells, respectively. The levels of M1 and M2 macrophages are of great importance for the immune system homeostasis [60]. Curcumin poses a stimulatory effect on Th1 cells and an inhibitory effect on Th2 cells, regulating the Th1/Th2 balance in ovalbumin-sensitized rats. Curcumin exhibits protective effects against immunotoxicity induced by 2-amino-3-methylimidazole (4,5-f) quinoline, which diminishes the percentage of blood lymphocytes [61]. It has also been reported that curcumin attenuates myasthenia gravis via the regulation of various immune cells [62]. Specifically, it inhibits the expression of $\mathrm{T}$ cell co-stimulatory molecules, shifts the balance from Th1/Th17 toward Th2/Treg, increases the number of NKR-P1+ cells, and promotes the differentiation of B cells into a subset of B10 cells. Also, an in vitro study of bone marrow-derived mesenchymal stem cells with curcumin shows an increasing trend towards M2 macrophage polarization, providing a favorable immune microenvironment for cutaneous wound healing [60]. Moreover, curcumin mediates a lower level of macrophage infiltration and inhibits NF- $\mathrm{kB}$ activation in macrophages [63]. An in silico study indicates that the antioxidant property and strong binding affinity with CD4 and CD8 receptors of curcumin inhibit the thymic apoptosis induced by deltamethrin [64]. Furthermore, curcumin has been reported to provide a protection of immunity by reversing type- 2 cytokine bias, reducing the Treg cell population, and inhibiting $T$ cell apoptosis [65].

In fish fed with the dietary curcumin, it has been observed that the lysozyme activity, total IgG, and IgM levels increase after curcumin treatment, suggesting an effect on improving the immune responses to Aeromonas hydrophila [66]. For the weaned piglets orally administered with 
the enterotoxigenic Escherichia coli, the treatment of curcumin increases the secretory immunoglobulin (sIgA), improving the immune status [67]. Moreover, curcumin is able to modulate the production of immune mediators. For example, it can induce the increase of IFN- $\gamma$ as well as the decrease of IL-1 $\beta$, IL-4, IL-6, IL-17A, and TNF- $\alpha[58,67,68]$.

Overall, curcumin mainly improves the immune system via the interaction with immune cells, such as lymphocytes and macrophages. Also, curcumin induces immune responses by modulating immune molecules, such as IgG, IgM, and sIgA.

\section{Health Benefits of Curcumin}

\subsection{Anticancer Effect}

Over the past decade, cancer death rates have remained at a high level [69]. Curcumin is shown to have anticancer potential for the prevention and treatment of different cancers [70,71]. The underlying anticancer mechanisms of curcumin mainly depend on the inhibition of cancer cell growth, induction of cancer cell apoptosis, and suppression of cancer cell metastasis [70,72,73].

\subsubsection{Inhibition of Cancer Cell Growth and Proliferation}

The observation on head-neck squamous cell carcinoma (HNSCC) cells indicates that the short-term exposure of curcumin at low concentrations results in the inhibition of colony formation as well as the growth of cells [73]. In vitro studies show that the treatment with curcumin causes $65 \%$ and $55 \%$ inhibition of cell proliferation in human nasopharyngeal carcinoma cell lines, CNE1 and CNE2, respectively [72]. In addition, curcumin treatment in vivo at the doses of 1000 and $1500 \mathrm{mg} / \mathrm{kg}$ leads to a $21.03 \%$ and $35.57 \%$ inhibition of the tumor growth, respectively, compared to the group of cervical cancer implanted nude mice [74]. Moreover, when curcumin is combined with other chemo drugs, like silymarin and paclitaxel, it shows a synergistic anticancer effect, exhibiting a higher inhibition on the growth of cancer cells $[75,76]$.

The antiproliferative effect of curcumin is associated with the regulation of many signal pathways and transcription factors. Immunoblot analysis of HNSCC cells show that due to the exposure of curcumin, phosphorylation of NF- $\mathrm{KB}$ and signal transducer and activator for transcription 3 (STAT3) are reduced and the expressions of cyclin D1 and cyclin D2 are suppressed, contributing to the antiproliferative effect of curcumin [73]. In addition, it has been demonstrated that curcumin downregulates the expression of yes-associated protein 1 (YAP) and transcriptional coactivator with PDZ-binding motif (TAZ), two transcriptional co-activators with oncogenic effects, inhibits Notch-1 gene expression, and reduces cell proliferation induced by the overexpression of YAP [77]. Furthermore, curcumin reduces cell proliferation through the regulation of miR-7/Skp2 by upregulating miR-7 expression and subsequently suppressing S-phase kinase-associated protein 2 (Skp2) [72]. In addition, curcumin pre-treatment has been observed to inhibit the growth of breast cancer cells in rats via activation of PPAR- $\gamma$ and decreasing the expression of brain-derived neurotrophic factor (BDNF) [78]. Moreover, an in vivo study shows that curcumin administration results in the downregulation of proliferating cell nuclear antigen (PCNA) as well as STAT3 expression [79]. Additionally, it is observed that nano-curcumin is effective in suppressing the proliferation of esophageal squamous cell carcinoma KYSE-30 and downregulating the expression of cyclin D1 [80].

Interference of the cell cycle inhibits cellular proliferation in various cancers. Curcumin induces the cell cycle arrest accompanied with irregular alterations in the number of cells in different phases, such as the $G_{1} / S$ and $G_{2} / M$ phases [81,82]. In Ras-activated HAG-1 human adenocarcinoma cells, curcumin treatment increases the proportion of cells in the $\mathrm{G}_{2} / \mathrm{M}$ phase from $20 \%$ to $52 \%$, and decreases the proportion of cells in the $S$ and $G_{0}-G_{1}$ phases, suggesting that the arrest in the $G_{2} / M$ phase can mediate a growth decline [83]. In Patu8988 pancreatic cancer cells, the accumulation of cell population in the $\mathrm{G}_{2} / \mathrm{M}$ phase increases from $15.07 \%$ to $19.59 \%$ and $23.75 \%$ with 10 and $15 \mu \mathrm{M}$ of curcumin, respectively [77]. The cell cycle analysis shows that the $\mathrm{G}_{2} / \mathrm{M}$ phase fraction is increased from $7.29 \%$ to 
$38.99 \%$ and $51.94 \%$ with $5 \mu \mathrm{M}$ and $10 \mu \mathrm{M}$ of curcumin in the CNE1 cells, respectively [72]. Moreover, the synergistic effect of curcumin and diclofenac has been found to inhibit telomerase activity and upregulate the tumor suppressor proteins, $\mathrm{p} 51, \mathrm{Rb}$, and p21, in colorectal cancer with the induction of cell cycle arrest [84]. In addition, apigenin and curcumin synergistically block the cell cycle progression in the $\mathrm{G}_{2} / \mathrm{M}$ phase of A549 cells with an increase of the expression of p53 [85].

Angiogenesis is strictly controlled in normal tissues, while it loses control in the tumor and promotes tumor formation. Curcumin is considered as an angiogenesis inhibitor, and leads to tumor regression and inhibition of tumor growth [86]. A high dose of curcumin reduces cervical cancer-induced increase in capillary networks and attenuates abnormalities of the capillary network pattern [74]. These effects are probably related to the downregulation of angiogenic biomarkers, including vascular endothelial growth factor (VEGF), COX-2, and epidermal growth factor receptor (EGFR). Additionally, the combination of doxorubicin and curcumin in $\mathrm{pH}$-sensitive nanoparticles constituted with amphiphilic poly ( $\beta$-amino ester) copolymer exert anti-angiogenesis effect by increasing the expression phosphor-VEGF receptor 2 and the suppression of all signaling proteins related to VEGF-induced pathways [87].

\subsubsection{Induction of Cancer Cell Apoptosis}

Curcumin has exhibited anticancer effects via inducing apoptosis in a variety of cancers. The apoptosis induced by curcumin leads to the morphological alternations of cancer cells, including cell shrinkage, cytoplasmic blebbing, irregularity in shape, and externalization of cell membrane phosphatidylserine [88]. The apoptosis mechanism of curcumin involves certain biomolecules and several signal pathways [89]. The derivates and complexes of curcumin can also induce the apoptosis of cancer cells, which may provide more application possibilities in cancer therapy [90].

Bcl-2 family proteins are key mediators in the regulation of cell death by inhibiting or inducing apoptosis. The anti-apoptotic proteins mainly contain B-cell lymphoma-2 (Bcl-2), Bcl-xL, and myeloid cell leukemia 1 (Mcl-1), while Bcl-2-associated X protein (Bax), Bcl-2 homologous antagonist killer (Bak), Bcl-xS, and Bcl-2-interacting killer (Bik) are pro-apoptotic proteins. In Src-activated HAG-1 human adenocarcinoma cells, curcumin inhibits cell growth by suppressing the level of Bcl-xL and activating the expression of Bax [83]. Curcumin promotes apoptosis in HNSCC cells by upregulating pro-apoptotic Bik prior to the suppression of cell proliferation [73]. Moreover, curcumin has been demonstrated to downregulate $\mathrm{Mcl}-1$ gene expression in MCF-7 breast cancer cells, decreasing the viability of cancer cells [91]. Additionally, the combination of paclitaxel and curcumin increases anti-tumor efficacy in mouse models, reduces the expression of Bcl-2, and increases the expression of Bax [75].

Regulation of apoptosis in cancer cells is associated with modulation of several signaling pathways. Curcumin has been reported to decrease the viability of human lung cancer A549 cells and induce apoptosis as well as autophagy [70]. Apoptosis and autophagy by curcumin are related to the downregulation of phosphatidylinositol 3-kinase (PI3K)/protein kinase B (Akt)/mammalian target of rapamycin (mTOR) pathway. In ovarian cancers, there is an abnormal increase in the expression of sarco/endoplasmic reticulum calcium ATPase (SERCA) [92], which can regulate $\mathrm{Ca}^{2+}$ homeostasis, and curcumin treatment has been found to suppress SERCA activity, leading to the disruption of $\mathrm{Ca}^{2+}$ homeostasis, and apoptosis of ovarian cancer cells. Recent studies demonstrate that the activity of leucine-zipper and sterile-alpha motif kinase alpha (ZAK $\alpha)$ is inhibited by curcumin, suggesting the involvement of apoptosis induction by curcumin [93]. Also, in colorectal cancer cells, curcumin increases p53 expression in tumor cells and modulates the tumor cell apoptotic pathway, promoting apoptosis of tumor cells [94]. Several studies indicate that curcumin and its analog can suppress the expression of miR-21, cyclin D1, and antigen Ki-67, but enhance the expression of phosphatase and tensin homolog (PTEN), programmed cell death protein 4 (PDCD4), and miR-21 target genes, resulting in induced apoptosis and antiproliferation in cancer cells $[95,96]$. Additionally, the polymeric 
nano-encapsulation of curcumin reduces the expressions of hypoxia-inducible factor 1- $\alpha$ (HIF 1- $\alpha)$ and nuclear p65 (Rel A), and subsequently induces apoptosis in breast and lung cancer cells [97].

The combination of curcumin and other components exhibits synergetic anticancer activity on inducing apoptosis of various cancer cells. On cell line models (A549, Hep-G2, MCF-7, Jurkat, and K562), the combination of berberine and curcumin causes more than $77 \%$ cell death, while the curcumin alone or berberine alone causes less than $54 \%$ or $45 \%$ cell death, respectively [98]. Compared with only curcumin or silymarin treatment, the combination treatment of curcumin and silymarin induces five-fold higher caspase 3/7 activities and a higher level of apoptosis in colon cancer cells [76]. In addition, the co-treatment of curcumin with cisplatin triggers ROS production, caspase-3 activation, and upregulation of p-ERK1/2 (ERK, Extracellular signal-regulated kinases), increasing the apoptosis rate of bladder cancer cells [99].

Curcumin is also considered as an auxiliary agent, and intensifies the therapeutic effects of other cancer treatments. When used in irradiation therapy, curcumin prevents radiation-induced activation of the NF- $\mathrm{B}$ p pathway, increases sensitivity to ionizing radiation and apoptosis of tumor cells, and decreases tumor cell proliferation, improving anticancer efficacy [100]. Moreover, the addition of curcumin is found to potentiate 5-fluorouracil-induced reduction of proliferation and invasion in colorectal cancer cells [101], and curcumin enhances the chemosensitivity of colorectal cancer cells to 5-fluorouracil and induces apoptosis. These effects are speculated to be associated with the downregulation of NF-kB activation, inhibition of AMP-activated protein kinase (AMPK)/unc-51-like kinase (ULK1)-dependent autophagy, and the suppression of Akt activity [102].

\subsubsection{Suppression of Cancer Cell Metastasis and Invasion}

Metastasis and invasion promote the spread and growth of various cancer cells. Several studies have reported that curcumin exhibits its anticancer activity by suppressing metastasis and invasion progression of cancer cell lines, which can be a promising therapeutic target for cancers [103]. Anti-metastatic and anti-invasive mechanisms of curcumin are involved in the inhibition of transcription factors, inflammatory cytokines, proteases, protein kinases, and the regulation of miRNAs [104]. Wound healing and transwell assays show that following curcumin treatment, metastasis and invasion into the Matrigel-coated membrane of nasopharyngeal carcinoma (NPC) cells are remarkably inhibited [72]. Compared with pure curcumin, catanionic lipid nanosystems incorporating curcumin show a 1.8-fold higher anti-invasion capacity on Lewis lung cancer cells [105]. Polymeric micelles of curcumin prepared in a thermosensitive hydrogel system have been identified to possess higher inhibitory effects against tumors in the colorectal peritoneal carcinomatosis mouse model, and the growth and metastasis of tumors are suppressed by the curcumin complexes, and the survival of tumor-bearing mice is prolonged [106].

Collectively, curcumin has shown anticancer effects on various cancer cells, such as breast, lung, and colon cancer cells [107]. As shown in Table 1 and Figure 4, the mechanisms of action are mainly associated with cell growth, proliferation, angiogenesis, apoptosis, metastasis, and invasion [108]. In addition, the association of curcumin with other components and anticancer therapy has a synergic effect to improve the prevention and treatment of cancers. 
Table 1. Anticancer activity and related molecular mechanisms of curcumin.

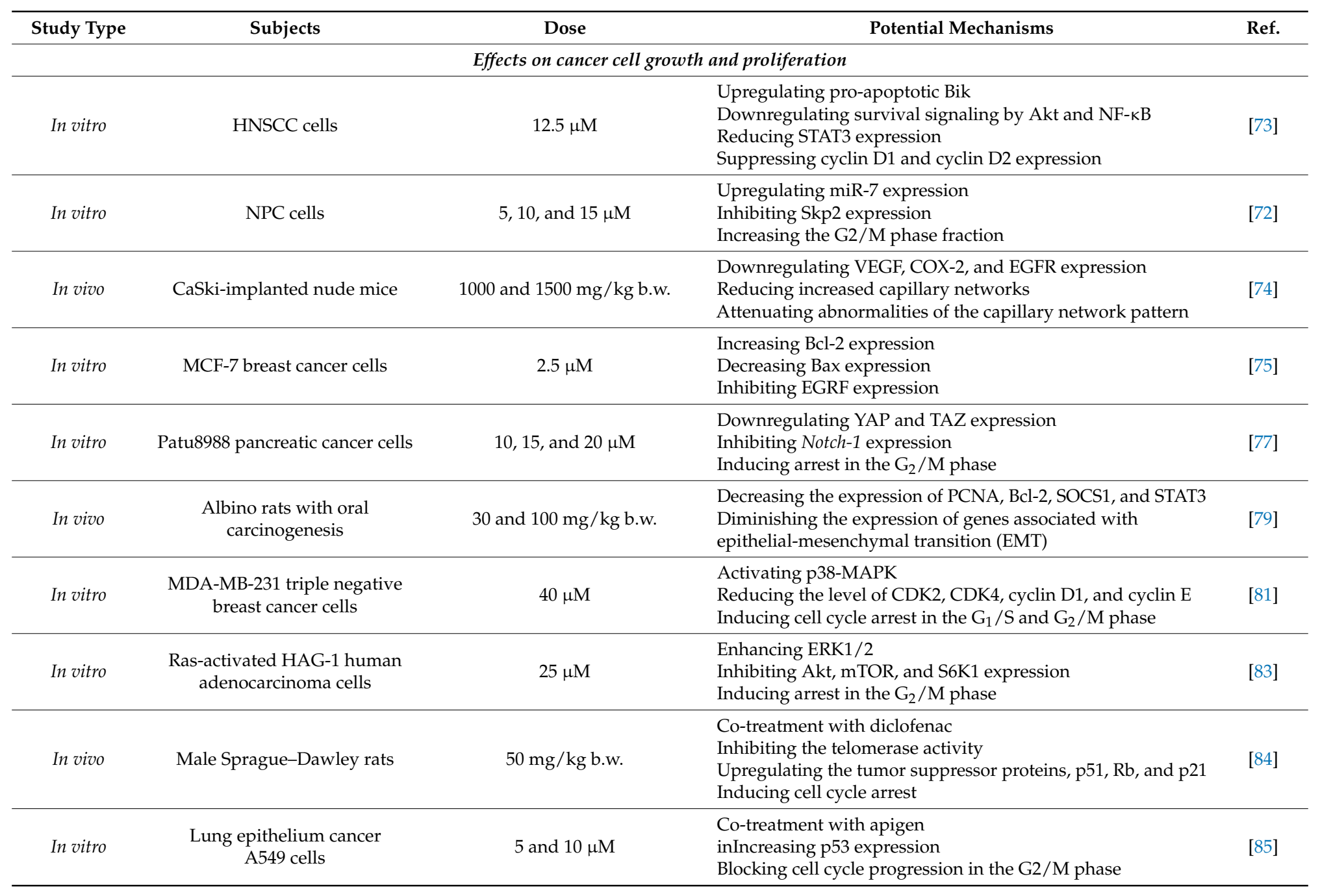


Table 1. Cont.

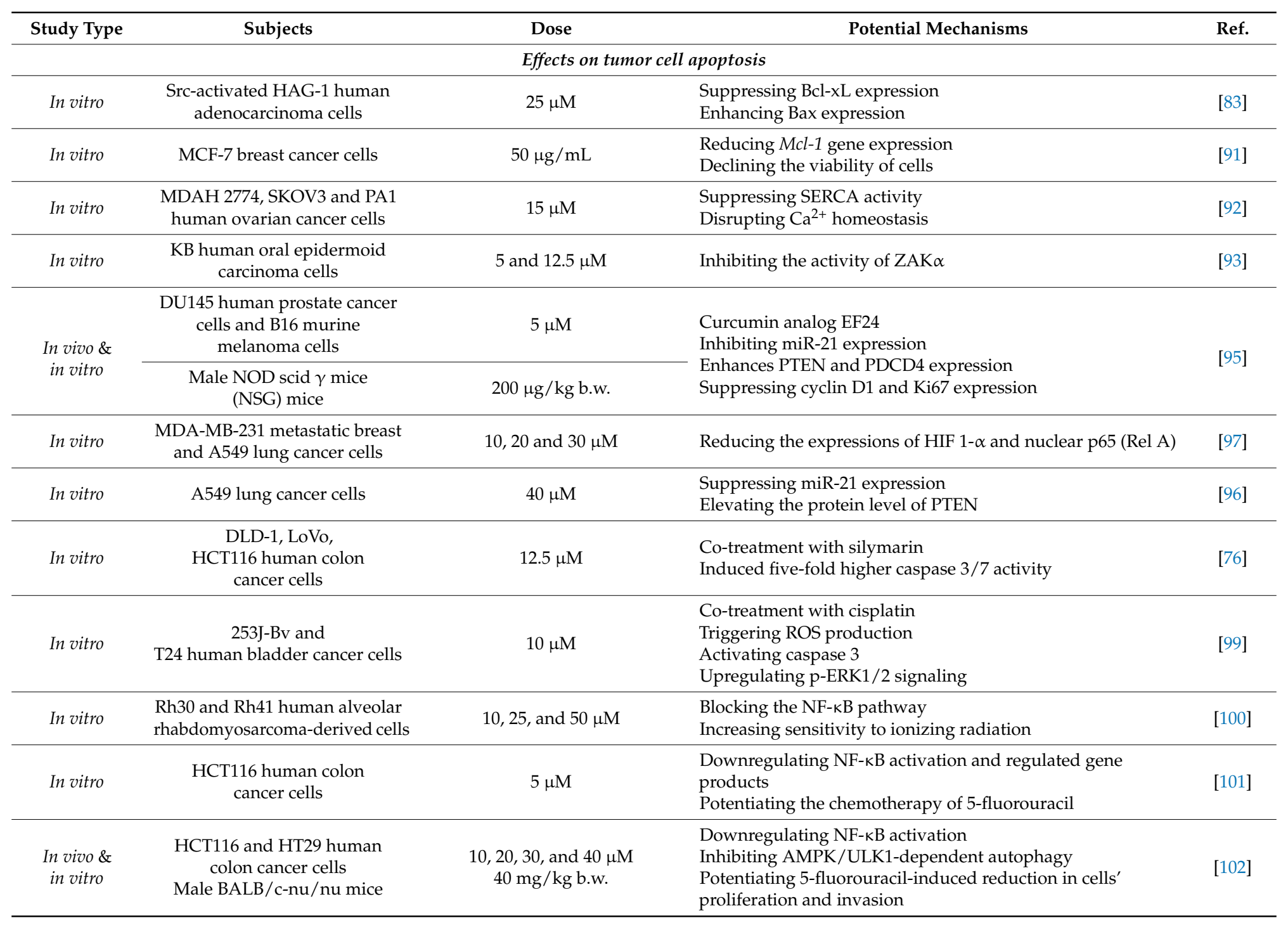


Table 1. Cont.

\begin{tabular}{lcccc}
\hline Study Type & Subjects & Dose & Potential Mechanisms \\
\hline \multicolumn{1}{c}{ In vitro } & NPC cells & Effects on metastasis and invasion & \\
\hline In vitro & Lewis lung cancer cells & 5,10, and $15 \mu \mathrm{M}$ & $\begin{array}{l}\text { Inhibiting cell motility } \\
\text { Suppressing invasion into the Matrigel-coated membrane }\end{array}$ & [72] \\
\hline
\end{tabular}

Akt, Protein kinase B; AMPK, AMP-activated protein kinase; Bax, Bcl-2-associated X protein; Bcl-2, B-cell lymphoma 2; Bcl-xL, B-cell lymphoma-extra large; Bik, Bcl-2-interacting killer; COX-2, Cyclooxygenase-2; EGFR, Epidermal growth factor receptor; ERK1/2, extracellular signal-regulated kinases; HNSCC, Head-neck squamous cell carcinoma; MAPK, Mitogen-activated protein kinase; mTOR, Mammalian target of rapamycin; NF-kB, Nuclear factor kB; NPC, Nasopharyngeal carcinoma; PCNA, Proliferating cell nuclear antigen; PTEN, Phosphatase and tensin homolog; ROS, Reactive oxygen species; S6K1, p70-S6 kinase 1; SERCA, Sarco/endoplasmic reticulum calcium ATPase; Skp2, S-phase kinase-associated protein 2; SOCS1, Suppressor of cytokine signaling 1; STAT3, Signal transducer and activator for 254 transcription 3; TAZ, Transcriptional coactivator with PDZ-binding motif; ULK1, Unc-51-like kinase; VEGF, Vascular endothelial growth factor; YAP, Yes-associated protein 1; ZAK $\alpha$, Leucine-zipper and sterile-alpha motif kinase alpha. 


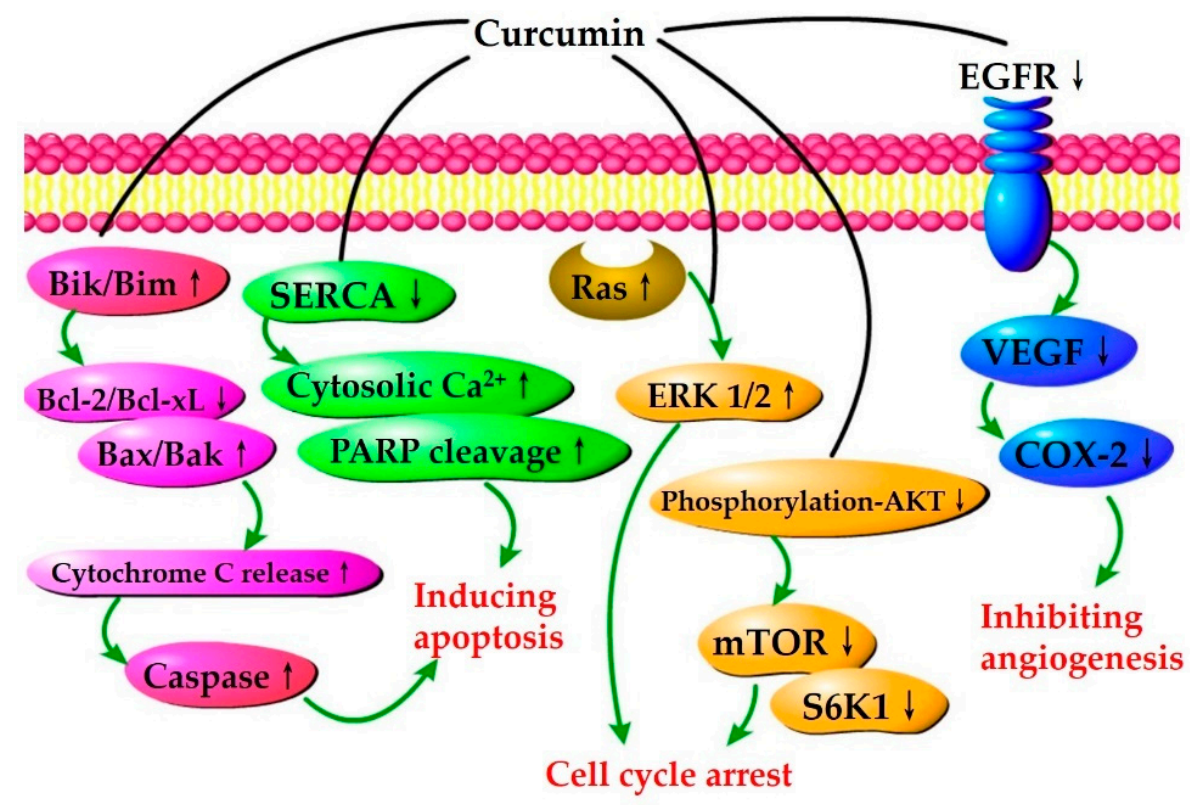

Figure 4. Curcumin-mediated anticancer signaling pathways, associated with the induction of apoptosis and cell cycle arrest, as well as the inhibition of angiogenesis. The up arrows indicate the upregulation, while the down arrows indicate the downregulation. Bcl-2, B-cell lymphoma 2; Bcl-xL, B-cell lymphoma-extra large; Bik, Bcl-2-interacting killer; Bim, Bcl-2 interacting mediator of cell death; Bax, Bcl-2-associated X protein; Bak, Bcl-2 homologous antagonist killer; SERCA, Sarco/endoplasmic reticulum calcium ATPase; PARP, Poly (ADP-ribose) polymerase; Ras, an oncogene product in many human cancers; ERK1/2, Extracellular signal-regulated kinases; Akt, Protein kinase B; mTOR, Mammalian target of rapamycin; S6K1, p70-S6 kinase 1; EGFR, Epidermal growth factor receptor; VEGF, Vascular endothelial growth factor; COX-2, Cyclooxygenase-2.

\subsection{Hepatoprotection}

Numerous studies indicate that curcumin exhibits hepatoprotective effects on acute and chronic liver injuries induced by pollutants, drugs, and alcohol, nonalcoholic fatty liver disease, and liver fibrosis $[109,110]$.

\subsubsection{Liver Injuries Induced by Pollutants, Drugs, and Alcohol}

Carbon tetrachloride $\left(\mathrm{CCl}_{4}\right)$, a well-known hepatotoxin pollutant, can induce acute or chronic liver injuries, and result in a high level of ROS, mitochondrial dysfunction, and cellular apoptosis [111]. Nanoparticulated curcumin has been evidenced to maintain cellular ROS levels, increase cellular antioxidant enzymes, prevent excessive mitochondrial destruction, and decrease fatty changes and inflammation in $\mathrm{CCl}_{4}$-treated rat hepatocytes [112]. Enzymes, such as aspartate aminotransferase (AST) and alanine transaminase (ALT), in serum, are the main liver transaminases for liver damage assessment, and the hepatic GSH content indicates oxidative stress in the liver [113]. Turmeric extract and curcumin are found to suppress $\mathrm{CCl}_{4}$-induced hepatic oxidative stress. They decrease the activities of serum aspartate aminotransferase (AST) and alanine transaminase (ALT) and the level of lipid peroxidase, while increasing the hepatic GSH content [114]. Additionally, curcumin is able to reduce the number of apoptotic hepatocytes induced by cadmium accumulation [115].

The intake of overdose drugs may cause severe side-effects, like hepatoxicity. Curcumin has been reported to ameliorate streptozotocin-induced liver injury of diabetic rats by decreasing hepatic endoplasmic reticulum stress marker protein and the sub-arm of unfolded protein response signaling protein, and inhibiting TNF- $\alpha$, IL1 $\beta$, phospho-p38 MAPK, and ASK1 in liver [116]. Paracetamol-induced mitochondrial dysfunction in hepatocytes is also attenuated by curcumin. 
It decreases oxygen consumption in the membrane potential, ATP synthesis, aconitase activity, and the activity of respiratory complexes, I, III, and IV [117].

Alcoholic liver disease is characterized by the disturbance of alcohol and lipid metabolism. A metabolomic pathway analysis shows that curcumin attenuates ethanol-induced liver injury by inhibiting the biosynthesis of unsaturated fatty acids, and interconversions of pentose and glucuronate [118]. In addition, curcumin dose-dependently attenuates the hepatocyte necroptosis and alcohol-induced decrease in hepatic Nrf2 expression in alcoholic mice [119].

\subsubsection{Nonalcoholic Fatty Liver Disease}

Nonalcoholic fatty liver disease (NAFLD) is acknowledged as a hepatic disease with multiple risk factors [120]. NAFLD is often accompanied by changes in metabolic and non-metabolic processes, like dyslipidemia, inflammation, and oxidative stress. Recently, curcumin has been reported to possess therapeutic efficacy in NAFLD experimental models, including non-alcoholic steatohepatitis (NASH) [121]. Oral administration of curcumin effectively protects against the progression of NAFLD induced by a high-fat diet through alternations in the metabolism, and the intrahepatic $\mathrm{CD} 4^{+}$cell accumulation [122]. Furthermore, high mobility group box 1 (HMGB1) is demonstrated to interact with TLR4, and induce nuclear translocation of activated NF- $\mathrm{KB}$, releasing pro-inflammatory cytokines [123]. Curcumin can reduce cytoplasmic translocation of HMGB1, the level of TLR4 protein expression, and the nuclear translocation of NF- $\mathrm{kB}$ [124]. Moreover, some studies elucidate that curcumin exhibits its hepatoprotective property by inhibiting transient receptor potential melastatin 2 (TRPM2) channels, and curcumin can restore $\mathrm{Ca}^{2+}$ levels, reduce oxidative stress, and lower the risk of NASH [125].

\subsubsection{Liver Fibrosis}

Liver fibrosis is the excessive accumulation of scar tissue induced by inflammation and liver cell death in chronic liver diseases, and it is affected by various factors, like overconsumption of alcohol or exposure to toxic chemicals. The hepatic stellate cell (HSC), the major fibrogenic cell in the liver, is involved in fibrosis, forming scar tissue in response to liver damage. Administration of curcumin has been reported to reduce the viability of HSCs by inhibiting the proliferation and stimulating endoplasmic reticulum stress [126]. Curcumin also suppresses the TGF- $\beta$ /Smad signaling pathway and blocks the production of extracellular matrix proteins in HSCs. A novel target for liver fibrosis treatment is to modulate the cannabinoid receptors (CBRs) system. Curcumin can also reduce the extracellular matrix overproduction in HSCs through the downregulation of CBR type 1 and upregulation of CBR type 2 [127]. Further investigations reveal that curcumin inhibits the angiogenesis in liver fibrosis. Curcumin reduces the angiogenic properties of HSCs, disrupts the platelet-derived growth factor- receptor (PDGF-R)/ERK and mammalian target of rapamycin (mTOR) pathways, and regulates activation of PPAR- $\gamma$ [128]. In addition, curcumin can suppress liver fibrosis via miRNA-mediated epigenetic regulation. It has been reported that curcumin upregulates miR-29b expression with the downregulation of DNA methyltransferase $3 \mathrm{~b}$ as well as the upregulation of PTEN, which inhibits the activated HSCs [129]. Furthermore, details of the hepatoprotective activity of curcumin are also shown in Table 2. 
Table 2. Hepatoprotection and related molecular mechanisms of curcumin.

\begin{tabular}{|c|c|c|c|c|}
\hline Study Type & Subjects & Dose & Potential Mechanisms & Ref. \\
\hline \multicolumn{5}{|c|}{ Liver injuries induced by pollutants, drugs, and alcohol } \\
\hline In vivo & $\begin{array}{l}\text { Swiss albino rats with } \mathrm{CCl}_{4} \\
\text { hepatotoxicity }\end{array}$ & $8.98 \mu \mathrm{M}$ & $\begin{array}{l}\text { Maintaining cellular ROS levels } \\
\text { Increasing the level of GR and GST } \\
\text { Decreasing the level of NADH oxidase } \\
\text { Increasing the activity of SDH }\end{array}$ & [112] \\
\hline In vivo & $\begin{array}{l}\text { Sprague-Dawley rats with } \mathrm{CCl}_{4} \\
\text { hepatotoxicity }\end{array}$ & $200 \mathrm{mg} / \mathrm{kg}$ b.w. & $\begin{array}{l}\text { Decreasing the activities of AST and ALT and the level of lipid peroxidase } \\
\text { Increasing hepatic GSH content }\end{array}$ & [114] \\
\hline In vivo & $\begin{array}{l}\text { Sprague-Dawley rats with diabetes } \\
\text { induced by streptozotocin }\end{array}$ & $100 \mathrm{mg} / \mathrm{kg}$ b.w. & $\begin{array}{l}\text { Decreasing hepatic endoplasmic reticulum stress marker protein and the } \\
\text { sub-arm of unfolded protein response signaling protein } \\
\text { Inhibiting TNF- } \alpha \text {, IL1 } \beta \text {, phospho-p38 MAPK, and ASK1 in liver tissues }\end{array}$ & [116] \\
\hline In vivo & $\begin{array}{l}\text { CD1 mice with paracetamol } \\
\text { hepatotoxicity }\end{array}$ & 35,50 , and $100 \mathrm{mg} / \mathrm{kg}$ b.w. & $\begin{array}{l}\text { Attenuating the decrease in oxygen consumption in the membrane } \\
\text { potential, ATP synthesis, aconitase activity, and activity of respiratory } \\
\text { complexes, I, III, and IV }\end{array}$ & [117] \\
\hline In vivo & $\begin{array}{l}\text { Kunming mice with alcoholic } \\
\text { fatty liver }\end{array}$ & $60 \mathrm{mg} / \mathrm{kg}$ b.w. & $\begin{array}{l}\text { Suppressing ethanol-induced pathways, including biosynthesis of } \\
\text { unsaturated fatty acids, fatty acid biosynthesis, and pentose and } \\
\text { glucuronate interconversions } \\
\text { Inhibited glyoxylate, dicarboxylate, and pyruvate metabolism }\end{array}$ & [118] \\
\hline In vivo & $\begin{array}{l}\text { Male ICR mice with alcoholic } \\
\text { fatty liver }\end{array}$ & $20 \mu \mathrm{M}$ & $\begin{array}{l}\text { Attenuating hepatocyte necroptosis } \\
\text { Increasing hepatic Nrf2 expression }\end{array}$ & [119] \\
\hline \multicolumn{5}{|c|}{ Nonalcoholic fatty liver disease } \\
\hline \multirow{2}{*}{ In vivo } & Peripheral blood mononuclear cells & $10 \mu \mathrm{M}$ & \multirow{2}{*}{$\begin{array}{l}\text { Reducing cytoplasmic translocation of HMGB1, protein expression of TLR4, } \\
\text { and nuclear translocation of NF-KB } \\
\text { Suppressing glypican-3 expression, VEGF, and pro-thrombin in NASH liver }\end{array}$} & \multirow{2}{*}[124]{} \\
\hline & $\begin{array}{l}\text { C57BL/6J mice with } \\
\text { NASH-hepatocellular carcinoma }\end{array}$ & $100 \mathrm{mg} / \mathrm{kg}$ b.w. & & \\
\hline In vivo \& in vitro & C57BL/6J mice with NAFLD & $2 \mathrm{~g}$ curcumin $/ \mathrm{kg}$ of diet & $\begin{array}{l}\text { Preventing high-fat diet-induced liver injury, metabolic alterations, } \\
\text { and intrahepatic } \mathrm{CD} 4^{+} \text {cell accumulation } \\
\text { Reducing the pro-inflammatory and pro-oxidant effects on liver } \\
\text { macrophages. }\end{array}$ & {$[122]$} \\
\hline In vivo & TRPM2 knockout Hooded Wistar rats & $5 \mu \mathrm{M}$ & $\begin{array}{l}\text { Inhibiting the activation of TRPM2 channels } \\
\text { Restoring } \mathrm{Ca}^{2+} \text { levels } \\
\text { Reducing oxidative stress } \\
\text { Lowering the risk of NASH }\end{array}$ & {$[124]$} \\
\hline
\end{tabular}


Table 2. Cont.

\begin{tabular}{|c|c|c|c|c|}
\hline Study Type & Subjects & Dose & Potential Mechanisms & Ref. \\
\hline \multicolumn{5}{|c|}{ Liver fibrosis } \\
\hline In vivo & $\begin{array}{l}\text { Sprague-Dawley rats with } \\
\text { alcohol-induced hepatic fibrosis }\end{array}$ & $50 \mu \mathrm{M}$ & $\begin{array}{l}\text { Inhibiting HSCs proliferation } \\
\text { Stimulating endoplasmic reticulum stress } \\
\text { Suppressing the TGF- } \beta \text { /Smad signaling pathway } \\
\text { Reducing the viability of HSCs }\end{array}$ & [125] \\
\hline \multirow[t]{2}{*}{ In vivo \& in vitro } & $\begin{array}{l}\text { Sprague-Dawley rats with } \\
\mathrm{CCl}_{4} \text {-induced hepatic fibrosis }\end{array}$ & 100,200 , and $400 \mathrm{mg} / \mathrm{kg}$ b.w. & \multirow{2}{*}{$\begin{array}{l}\text { Reducing extracellular matrix overproduction in HSCs } \\
\text { Downregulating CBR type } 1 \\
\text { Upregulating CBR type } 2\end{array}$} & \multirow[t]{2}{*}{ [127] } \\
\hline & HSCs isolated from rats & 10,20 , and $30 \mu \mathrm{M}$ & & \\
\hline \multirow[t]{2}{*}{ In vivo \& in vitro } & $\begin{array}{l}\text { Sprague-Dawley rats with } \\
\mathrm{CCl}_{4} \text {-induced hepatic fibrosis }\end{array}$ & 100,200 , and $400 \mathrm{mg} / \mathrm{kg}$ b.w. & \multirow{2}{*}{$\begin{array}{l}\text { Disrupted PDGF-R/ERK and mTOR pathways } \\
\text { Activating PPAR- } \gamma \\
\text { Reducing the angiogenic properties of HSCs }\end{array}$} & \multirow[t]{2}{*}{ [128] } \\
\hline & HSCs isolated from rats & $20 \mu \mathrm{M}$ & & \\
\hline \multirow[t]{2}{*}{ In vivo \& in vitro } & $\begin{array}{l}\text { Sprague Dawley rats with } \\
\mathrm{CCl}_{4} \text {-induced hepatic fibrosis }\end{array}$ & $200 \mathrm{mg} / \mathrm{kg}$ b.w. & \multirow{2}{*}{$\begin{array}{l}\text { Upregulating miR-29b expression } \\
\text { Downregulating DNA methyltransferase } 3 b \\
\text { Upregulating PTEN } \\
\text { Inhibiting activated HSCs }\end{array}$} & \multirow[t]{2}{*}{ [129] } \\
\hline & Rat HSC-T6 cells & $20 \mu \mathrm{M}$ & & \\
\hline
\end{tabular}

ALT, Alanine transaminase; ASK1, Apoptosis signal-regulating kinase 1; AST, Aspartate aminotransferase; CBR, Cannabinoid receptors; CCl ${ }_{4}$, Carbon tetrachloride; CD4, Cluster of differentiation 4; ERK, Extracellular signal-regulated kinases; GR, Glutathione reductase; GSH, Glutathione; GST, Glutathione S-transferases; HMGB1, High mobility group box 1; HSCs, Hepatic stellate cells; ICR, Institute of Cancer Research; IL1 $\beta$, Interleukin 1 $\beta$; MAPK, Mitogen-activated protein kinase; mTOR, Mammalian target of rapamycin; NADH, Nicotinamide adenine dinucleotide; NAFLD, Nonalcoholic fatty liver disease; NASH, Non-alcoholic steatohepatitis; NF- $\mathrm{kB}$, Nuclear factor kB; Nrf2, Nuclear factor (erythroid-derived 2)-like 2; PDGF-R, Platelet-derived growth factor- receptor; PTEN, Phosphatase and tensin homolog; ROS, Reactive oxygen species; TGF- $\beta$, Transforming growth factor-beta; TLR4, Toll-like receptor 4;

TNF- $\alpha$, Tumor necrosis factor- $\alpha$; TRPM2, Transient receptor potential melastatin 2; SDH, Succinate dehydrogenase; VEGF, vascular endothelial growth factor 


\subsection{Neuroprotection}

Curcumin has shown the potential as a neuroprotective agent due to its antioxidant and anti-inflammatory activities and the ability to maintain the chemical balance in the brain [26]. Certain investigations reveal that curcumin pretreatment is effective to reduce $\mathrm{H}_{2} \mathrm{O}_{2}$-induced neurotoxicity in PC12 cells by attenuating caspase activation, poly (ADP-ribose) polymerase (PARP) cleavage, DNA damage, and the accumulation of ROS, and dysregulation of the MAPK and Akt pathways. These protective effects can be used in the therapy for human neurodegenerative diseases [130]. Furthermore, the neuroprotective property of curcumin can reduce $\mathrm{H}_{2} \mathrm{O}_{2}$-induced damage in the SH-SY5Y human neuroblastoma cell line, and enhance cell viability [131]. Anti-neuroinflammatory results elucidate that curcumin inhibits the secretion of pro-inflammatory mediators and cytokines, induces HO-1 transcription and translation, and modulates NF- $\mathrm{KB}$ and MAPK signaling pathways, reducing inflammation in microglial cells [132]. The suppression of inflammation by curcumin leads to the reduction in astrocyte hypertrophy and the activation of microglia in the hippocampus, contributing to a better memory and mood function [133]. Furthermore, the pretreatment of curcumin is also effective to attenuate brain trauma and improve neurological function, alleviate neuropathic pain, mitigate axonal injury, and protect against ischemia and reperfusion injury [134-138].

In vitro and in vivo studies have shown the potential of curcumin as an adjuvant for the treatment of neurodegenerative diseases, such as Alzheimer's disease (AD) and Parkinson's disease (PD). In neurodegenerative diseases, curcumin treatment can bind to some proteins or limit the aggregation of other protein to maintain homeostasis of the inflammatory system and facilitate the heat shock system [139]. Numerous studies acknowledge that the accumulation of amyloid- $\beta$ protein and hyperphosphorylated tau proteins is the hallmark of AD. Curcumin may directly bind to PPAR- $\gamma$ and increase transcriptional activity and protein levels of PPAR- $\gamma$, which alleviates amyloid- $\beta$-induced neuroinflammation and improves neuronal status in the rat $\mathrm{mAD}$ [140]. The toxicity of the amyloid- $\beta$ peptide damages spatial learning and memory through the c-Jun N-terminal kinase (JNK) signaling pathway in Aodel of D. After treating with curcumin, AD rats show restored spatial learning and memory deficits, and JNK-3 phosphorylation is inhibited [141]. In mice with AD, active avoidance and locomotor activity are improved by curcumin, which protects against neurodegeneration [142]. For PD, increasing evidence indicates that the accumulation of $\alpha$-synuclein protein plays a vital role in the occurrence of PD [143], suggesting that curcumin can reduce the accumulation of A53T $\alpha$-synuclein by downregulating the mTOR/ribosomal protein S6 kinase (p70S6K) signaling, and restoring macroautophagy. Curcumin prevents $\alpha$-synuclein from aggregating in the dopaminergic neurons at both the gene level and protein expression level [144]. Meanwhile, curcumin inhibits astrocytic activation, and reduces iron deposition on the dopaminergic neurons. Moreover, the cognitive function is impaired in mice with PD, while curcumin treatment in mice reduces the enhanced acetylcholine esterase enzyme levels, and restores the moto deficits, improving the cognitive functions [145]. Curcumin provides protection for neurons by reducing p-p28 expression, caspase- 3 activation, and toxic quinoprotein formation in 6-hydroxydopamine treated SH-SY5Y cells, ameliorating oxidative stress-related neurodegeneration, like PD [146].

It has been documented that the exposure to some heavy metals, medications, and chemicals can induce nerve injuries, and even neuropathology of several neurodegenerative disorders. Curcumin diminishes copper-induced neurotoxicity in vivo by upregulating tyrosine hydroxylase expression and restoring locomotor performance [147]. In addition, curcumin treatment can ameliorate arsenic-induced mitochondrial dysfunctions and modulate proteins related to apoptosis to reduce cholinergic deficits [148]. Additionally, curcumin has been reported to abrogate the neurotoxicity induced by some drugs. For example, curcumin is found to remarkably ameliorate the abnormal alternations caused by cisplatin, including thermal hypoalgesia, reduced sciatic motor nerve conduction velocity, and nuclear and nucleolar atrophy with the loss of neurons [149]. Bupivacaine, a widely-used anesthetic, has neurotoxicity in SH-SY5Y cells, and curcumin has been observed to protect against neuronal injury by increasing the level of Akt phosphorylation [150]. With the intervention of curcumin on pregnant 
mice, cultured neurons, and neural progenitor cells, results show that curcumin can mitigate the toxic effects of celecoxib on fetal brain development by suppressing the proliferation of neuronal progenitor cells via activation of the Wnt/ $\beta$-catenin pathway [151]. Furthermore, the treatment of curcumin has been reported to reduce colistin-induced neurotoxicity in neuroblastoma-2a through regulating NF- $\mathrm{kB}$ signaling, leading to antioxidative and anti-apoptotic responses [52]. Furthermore, toxic chemicals, like quinolinic acid, also impair the nervous system. Curcumin prevents rotation behavior, striatal morphological alterations, and neurodegeneration induced by quinolinic acid, and activates the Nrf2 cytoprotective pathway to induce antioxidant responses [152].

\subsection{Cardiovascular Protection}

Cardiovascular diseases (CVDs) have threatened human health severely worldwide. It has been documented that the intake of curcumin is beneficial to CVDs $[153,154]$.

Curcumin can protect cardiomyocytes as a cardio-protectant. For instance, curcumin protects against norepinephrine-induced hypertrophic stress and maintains extracellular matrix remodeling by inhibiting the increased collagen content under hypertrophic stress, and suppressing enhanced gelatinase B expression and gelatinolytic activity in $\mathrm{H} 9 \mathrm{c} 2$ cardiomyocytes [155]. It has also been found that curcumin prevents cardiomyocytes from norepinephrine-induced apoptosis and restores their physiological status [156]. In addition, the administration of curcumin can attenuate the cytotoxicity of hemiscorpius lepturus venom, which damages the mitochondrial respiratory chain and results in ATP depletion, death signaling, and consequent cardiomyocytes apoptosis [157]. Furthermore, curcumin increases the viability of $\mathrm{H} 9 \mathrm{c} 2$ cardiomyoblasts exposed to $\mathrm{H}_{2} \mathrm{O}_{2}$ by upregulating the $\mathrm{HO}-1$ protein, inhibiting cleaved caspase-3 protein expression, and increasing the Bcl-2/Bax ratio [158]. Additionally, curcumin prevents cardiomyocytes from high glucose-induced apoptosis via the inhibition of NADPH-mediated oxidative stress by modulating the PI3K/Akt signaling pathway [154].

It is reported that curcumin can ameliorate cardiac hypertrophy and preserve cardiac function by upregulating $\mathrm{Na}^{+} / \mathrm{Ca}^{2+}$ exchanger expression levels. The left ventricle (LV) end-systolic and diastolic dimensions are reduced, and the LV ejection fraction and LV fractional shortening are enhanced in vivo by curcumin [159]. Another work uses high doses of glucose and insulin to induce hypertrophy in cardiomyocytes and the treatment of curcumin decreases the increased ANF mRNA expression, total protein content, and cell surface area, resulting in attenuated cardiomyocyte hypertrophy [160]. Meanwhile, curcumin increases PPAR $-\gamma$ and Akt protein expressions, endothelial NO synthase (eNOS) mRNA expression, eNOS content, and NO concentration in cardiomyocytes. Curcumin is also found to suppress hypertrophic responses in cardiomyocytes by disrupting the formations of the zinc finger transcription factor, GATA4, and functional proteins, such as intrinsic histone acetyltransferase, and p300 [161]. Additionally, curcumin can attenuate chronic heart failure by increasing Dickkopf-related protein 3, p38 MAPK, JNK, and apoptosis signal-regulating kinase 1 (ASK1) [162]. Moreover, curcumin has been demonstrated to have hypocholesterolemic activity both in vitro and in vivo. Curcumin treatment is found to reduce cholesterol absorption in Caco-2 cells via downregulation of expressions of Niemann-Pick C1-like 1 (NPC1L1) and sterol regulatory element binding protein-2 (SREBP-2) [163].

The occurrence of CVDs is closely related with unbalanced diets. For curcumin, it protects the cardiomyocytes from injuries, and decreases cardiac hypertrophy, chronic heart failure, and cholesterol absorption.

\subsection{Anti-Diabetic Effect}

Diabetes mellitus (DM) has reached pandemic status and there have been numerous studies on the development of anti-diabetic drugs with fewer side effects [164]. Curcumin has been found to exhibit promising anti-diabetic activity, and curcumin intervention on prediabetic individuals can significantly lower the risk of developing type 2 DM [165]. Additionally, curcumin can be a potential alternative to prevent and treat diabetes as well as certain complications, such as diabetic retinopathy [166,167]. 
The anti-diabetic activity of curcumin commonly reflects on the control of hyperglycemia by downregulating $\alpha$-glucosidase and $\alpha$-amylase activity. In addition, curcumin is beneficial for insulin-producing and insulin-responsive tissue, such as liver, skeletal muscle, and adipose tissues [168]. Molecular docking in silico shows that curcumin poses a better inhibitory effect on $\alpha$-amylase than other natural compounds, such as quercetin and berberine [169]. After hyperglycaemic rats were administered with curcumin, the mean blood glucose level was significantly reduced [170]. Additionally, the glucose tolerance and insulin sensitivity of diabetic rats were enhanced after being treated with curcumin [171]. Meanwhile, the levels of Akt phosphorylation and glucose transporter type 4 (GLUT4) translocation in skeletal muscles are increased by curcumin. Moreover, in diabetic mice treated with curcumin for 12 weeks, pancreatic islets have no lymphocytes infiltration and there is an increase in the numbers of small islets of Langerhans near the ducts in the pancreas, which indicates an improvement of pancreatic islets [172].

\subsection{Other Health Benefits}

Curcumin has been documented to pose preventive and therapeutic effects on other diseases. For instance, curcumin exhibits anti-influenza virus activity, and it can inhibit type A influenza virus (IAV) infection through interference with the receptor binding region of viral haemagglutination (HA) protein, severely affecting viral HA activity [173]. Moreover, the results of blood compatibility tests demonstrate the antiplatelet property of curcumin. Fewer platelets adhered and aggregated on the surface with an increase in the content of curcumin [174]. Furthermore, chronic exposure to curcumin has been found to alleviate seizure activity induced by pentylenetetrazole in rats. It has also been observed that chronic curcumin pre-treatment increases the myoclonic jerks latency, while decreasing the duration of generalized tonic-clonic seizures and the severity of seizure [175]. Finally, the bioactivity and health benefits of curcumin are summarized in Figure 5 .

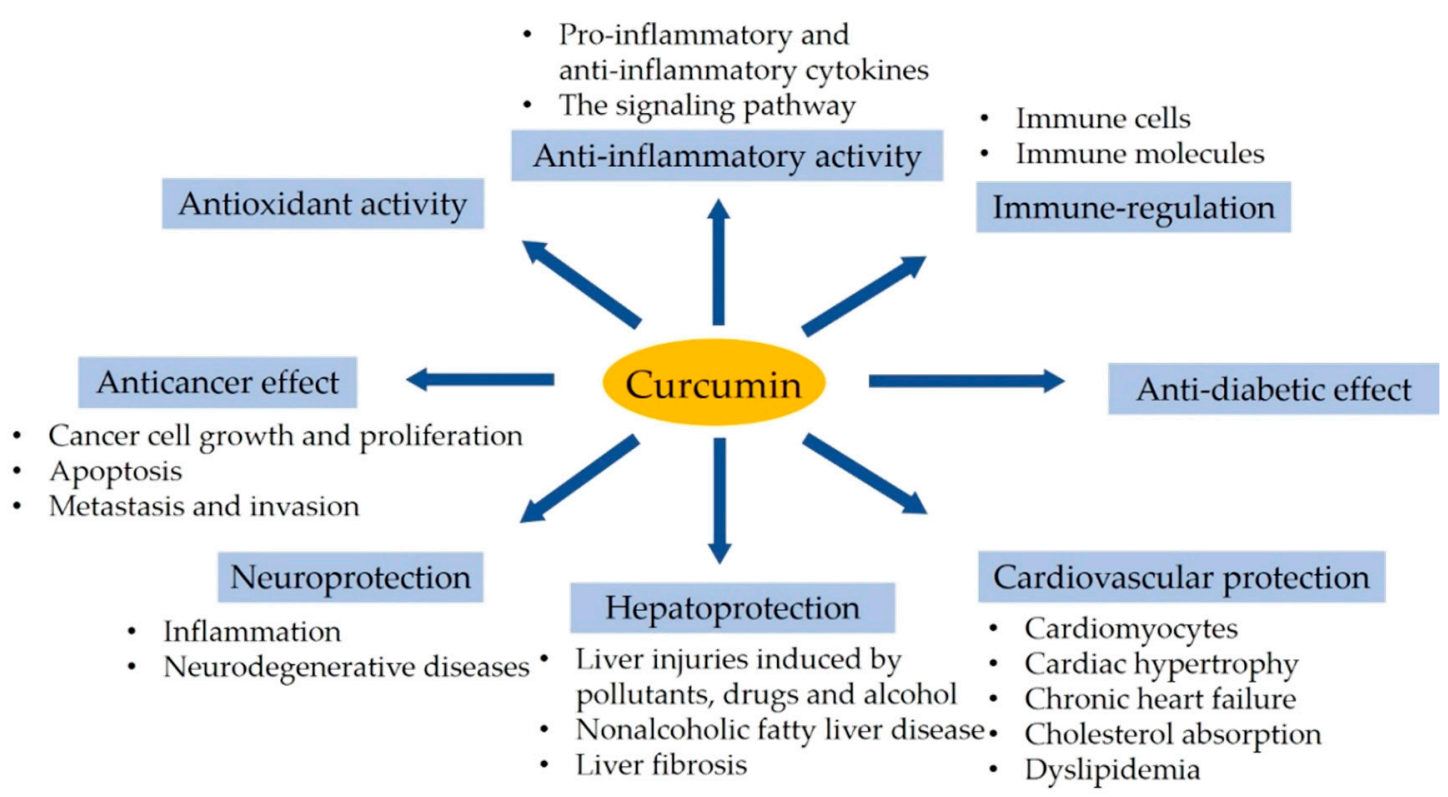

Figure 5. A summary of the bioactivity and health benefits of curcumin, including antioxidant, anti-inflammatory, immune-regulatory, anticancer, neuroprotective, hepatoprotective, cardiovascular protective, and anti-diabetic effects.

\section{Clinical Trials}

In the past five years, some clinical trials have been conducted to investigate the effects of curcumin on patients with several diseases, such as metabolic syndromes, diabetes, arthritis, and gut 
inflammation [176]. In clinical trials, curcumin is often used in combination with other agents or alone with delivery systems, such as nanoparticles and liposomal encapsulation [177,178].

Oxidative stress plays an important role in the progression of nondiabetic or diabetic proteinuric kidney disease. Specifically, a randomized double-blind placebo-controlled clinical trial was performed to evaluate the antioxidant effects of curcumin on chronic kidney disease (CKD). One hundred and one patients with nondiabetic or diabetic proteinuric CKD received a placebo or $320 \mathrm{mg}$ of curcumin per day for eight weeks. Results showed that curcumin attenuates lipid peroxidation in plasma in patients with nondiabetic proteinuric CKD and improved the antioxidant capacity in patients with diabetic proteinuric CKD [179].

Due to its anti-inflammatory activity, curcumin could provide an improvement on inflammatory diseases. Thirty-six patients with rheumatoid arthritis (RA, a chronic systemic inflammatory disorder) were randomly assigned to receive a placebo, $250 \mathrm{mg}$, or $500 \mathrm{mg}$ of curcumin twice daily for 90 days. At the end of the study, the clinical markers of inflammation, including erythrocyte sedimentation rate (ESR) and C-reactive protein (CRP) values, were significantly improved in the groups receiving curcumin [180]. In addition, the effects of curcumin on osteoarthritis (OA) were evaluated, and 22 patients with knee OA took three caps of bio-optimized curcumin twice a day. The treatment with curcumin significantly reduced the serum levels of Coll2-1, a cartilage-specific biomarker, attenuating knee OA [181]. Psoriasis vulgaris is a common chronic inflammatory disease. Sixty-three patients with mild-to-moderate psoriasis vulgaris were treated with $2 \mathrm{~g}$ of topical steroids and oral curcumin per day, or with topical steroids alone for 12 weeks. In patients treated with oral curcumin, the psoriasis area and severity index (PASI) values and serum levels of IL-22 were significantly reduced and the inflammation progression was ameliorated [182]. Similarly, patients with moderate-to-severe psoriasis were treated orally with $0.4 \mathrm{mg} / \mathrm{kg}$ of acitretin and $3 \mathrm{~g}$ of nanocurcumin or only with acitretin every day for 12 weeks. It resulted in reduced PASI values and unchanged cholesterol serum levels in patients treated with curcumin and acitretin [177]. Furthermore, migraines are characterized by high levels of IL- 6 and CRP, which disrupt the integrity of the blood-brain barrier and induce neurogenic inflammation. Eighty episodic migraine patients were randomized to receive a combination of $\omega-3$ fatty acids $(2500 \mathrm{mg}$ ) and nanocurcumin $(80 \mathrm{mg})$ or $\omega-3$ alone or nanocurcumin alone for two months. Notably, the combination of nanocurcumin and $\omega-3$ downregulated IL-6 mRNA and decreased the serum levels of IL-6 as well as high sensitivity CRP (hs-CRP) [183].

Curcumin supplements are considered as a preventive agent and an adjuvant therapy of cancers. Oral leukoplakia is a potentially malignant lesion of the oral cavity. Subjects with oral leukoplakia $(n=223)$ randomly took orally $3.6 \mathrm{~g}$ of curcumin $(n=111)$ or a placebo $(n=112)$ daily for six months. The primary endpoint was a clinical response obtained by bi-dimensional measurement of the leukoplakia size at six months of recruitment. At the end of the study, the treatment with curcumin had no safety concerns and the subjects were well tolerated and given a durable clinical response for six months [184]. Additionally, curcumin has been reported to have antitumor effects on glioblastoma cells in human. Thirteen glioblastoma patients received $70 \mathrm{mg}$ of micellar curcuminoids, consisting of curcumin, demethoxycurcumin, and bis-demethoxycurcumin, three times per day for four days. After the intervention of curcuminoids, the mean ratio of phosphocreatine to inorganic phosphate decreased, and the mean intratumoral $\mathrm{pH}$ increased, attenuating intratumoral energy metabolism [185].

In clinical trials, curcumin has also been demonstrated to show protection against cardiovascular diseases. The progression of atherosclerosis can be accelerated by alpha 1-antitrypsin-low-density lipoprotein (AT-LDL). Subjects with stages I-II chronic obstructive pulmonary disease (COPD) were randomly treated with $90 \mathrm{mg}$ of Theracurmin (R) (a highly absorptive curcumin using a drug delivery system) or a placebo twice a day for 24 weeks. The level of AT-LDL was significantly lower in the curcumin group compared with the placebo group [186]. The curcumin extract was evidenced to have a lipid-lowering effect via a clinical trial of 65 patients with metabolic syndromes. Patients were randomized into two groups to take a $630 \mathrm{mg}$ curcumin extract capsule or a placebo capsule thrice daily 
for 12 weeks. The level of high-density lipoprotein cholesterol (HDL-C) were significantly increased, and the levels of LDL and triglycerides were significantly reduced after curcumin extract treatment for 12 weeks [187]. A six-month clinical trial with type 2 diabetic patients shows that curcumin intervention significantly reduces pulse wave velocity, increases the level of serum adiponectin, and decreases the level of leptin, lowering the atherogenic risks [188]. A randomized double-blind placebo-controlled trial including 33 patients with coronary artery disease revealed that the intake of curcumin significantly ameliorates dyslipidemia in patients. Curcumin was observed to control the blood lipid levels by decreasing the serum levels of triglycerides, LDL-cholesterol, and very low density lipoprotein-cholesterol (VLDL-C) [189].

Curcumin supplementation may exert beneficial effects on the management of diabetes. In an open-label, randomized control trial, eight type-2 diabetic patients were treated with curcumin capsules on glyburide therapy for 10 days. Results show that the levels of blood glucose, LDL, VLDL, and triglycerides were decreased significantly, and the content of HLDL was increased. The findings indicate that the combination of curcumin capsules with glyburide contributes to better glycemic control in diabetic patients [190]. In addition, 70 type-2 diabetic patients randomly received $80 \mathrm{mg}$ of nano-micelle curcumin or a placebo daily for three months, and in the group with nano-micelle curcumin, a significant decrease was observed in glycated hemoglobin (HbA1C) and fasting blood glucose (FBG) which are biochemical parameters related to diabetes [191].

Overall, several clinical trials have demonstrated the beneficial effects of curcumin in patients with inflammation, cardiovascular diseases, metabolic syndrome, or diabetes.

\section{Challenges and Perspectives}

Curcumin has been documented to exhibit therapeutic or protective effects against a wide spectrum of diseases, but curcumin is unstable under various conditions and is easily degraded or metabolized into other forms. For instance, the dose of curcumin given orally is $8 \mathrm{~g} /$ day in humans, and the data shows that curcumin is rapidly transformed into metabolites, resulting in a low level of free curcumin in plasma $(<2.5 \mathrm{ng} / \mathrm{mL})$ [192]. The poor aqueous solubility and low bioavailability of curcumin are considered as the main obstacles to its clinical development, and the metabolites and derivatives may be responsible for the biological activities rather than free curcumin [7]. To enhance the stability and bioavailability of curcumin, many studies focus on modifications of curcumin and its delivery systems, such as nanoparticles, micellation, and conjugation with other materials [193-195]. Such modifications can increase its stability, solubility, in vivo uptake, bioactivity, and safety [196-200].

Recently, there have been different points of view on the beneficial effects of curcumin. It is argued that the therapeutic benefits of curcuminoids are skeptical, since they are unstable and nonbioavailable [2]. In addition, it is claimed that curcuminoids may interact with proteins to give false signals in drug screening tests, and the focus on curcuminoids is a waste of sources [201]. However, it is also considered that scientists should logically study natural products rather than asserting their inefficacy one-sidedly [202], as curcumin might be an important adjunctive treatment for certain diseases. In addition, it is stated that the clinical trials of curcumin should not be dismissed, curcumin really exhibits therapeutic benefits, and the binding of curcumin with other molecules is modulation rather than inhibition [203]. It is also emphasised that more large trials with controlled placebos are needed to verify the therapeutic effects of curcumin on the human body [204]. In light of the instability of curcumin, although its efficacy has been challenged, many animals and human studies, especially preclinical trails, still support the therapeutic and protective effects of curcumin, while more clinical trials are necessary to clarify its effects on human.

\section{Conclusions}

In conclusion, curcumin has been reported to exhibit versatile bioactivity and provide diverse health benefits to humans, such as antioxidant, anti-inflammatory, and anticancer activities. In addition, there are increasing studies on finding novel molecular targets of curcumin, and its mechanisms 
of actions are expected to be understood more clearly. Furthermore, it is promising to use the nanotechnology to encapsulate curcumin to improve its stability, bioavailability, bioactivity, and health benefits. Although there is still a debate about its beneficial effects on humans, numerous preclinical studies still support its health benefits due to their versatile bioactivity. Therefore, curcumin can be still a good natural ingredient for the development of relevant functional foods as promising alternatives for the prevention of certain chronic diseases.

Author Contributions: Conceptualization, X.-Y.X., R.-Y.G. and H.-B.L.; Writing-original draft preparation, X.-Y.X., X.M. and Y.L.; Writing-review and editing, S.L., R.-Y.G. and H.-B.L.; Supervision, R.-Y.G. and H.-B.L.; Funding acquisition, R.-Y.G. and H.-B.L.

Funding: This work was supported by the Shanghai Basic and Key Program (No. 18JC1410800), Shanghai Pujiang Talent Plan (No. 18PJ1404600), Shanghai Jiao Tong University Young Scholar Starting Funding, National Natural Science Foundation of China (No. 81372976), Key Project of Guangdong Provincial Science and Technology Program (No. 2014B020205002), and the Hundred-Talents Scheme of Sun Yat-Sen University.

Acknowledgments: We thanks Shi-Yu Cao for her assistance.

Conflicts of Interest: The authors declare no conflict of interest.

\section{References}

1. Maheshwari, R.K.; Singh, A.K.; Gaddipati, J.; Srimal, R.C. Multiple biological activities of curcumin: A short review. Life Sci. 2006, 78, 2081-2087. [CrossRef] [PubMed]

2. Nelson, K.M.; Dahlin, J.L.; Bisson, J.; Graham, J.; Pauli, G.F.; Walters, M.A. The essential medicinal chemistry of curcumin. J. Med. Chem. 2017, 60, 1620-1637. [CrossRef] [PubMed]

3. Awasthi, M.; Singh, S.; Pandey, V.P.; Dwivedi, U.N. Curcumin: Structure-activity relationship towards its role as a versatile multi-targeted therapeutics. Mini Rev. Org. Chem. 2017, 14, 311-332. [CrossRef]

4. Wang, R.; Li, J.B.; Zhao, Y.L.; Li, Y.P.; Yin, L. Investigating the therapeutic potential and mechanism of curcumin in breast cancer based on RNA sequencing and bioinformatics analysis. Breast Cancer 2018, 25, 206-212. [CrossRef] [PubMed]

5. Cao, J.; Wang, T.; Wang, M. Investigation of the anti-cataractogenic mechanisms of curcumin through in vivo and in vitro studies. BMC Ophthalmol. 2018, 18, 48. [CrossRef] [PubMed]

6. Pulido-Moran, M.; Moreno-Fernandez, J.; Ramirez-Tortosa, C.; Ramirez-Tortosa, M.C. Curcumin and health. Molecules 2016, 21, 264. [CrossRef] [PubMed]

7. Jankun, J.; Wyganowska-Swiatkowska, M.; Dettlaff, K.; Jelinska, A.; Surdacka, A.; Watrobska-Swietlikowska, D.; Skrzypczak-Jankun, E. Determining whether curcumin degradation/condensation is actually bioactivation (review). Int. J. Mol. Med. 2016, 37, 1151-1158. [CrossRef] [PubMed]

8. Holder, G.M.; Plummer, J.L.; Ryan, A.J. The metabolism and excretion of curcumin (1,7-bis-(4-hydroxy-3methoxyphenyl)-1,6-heptadiene-3,5-dione) in the rat. Xenobiotica 1978, 8, 761-768. [CrossRef] [PubMed]

9. Asai, A.; Miyazawa, T. Occurrence of orally administered curcuminoid as glucuronide and glucuronide/ sulfate conjugates in rat plasma. Life Sci. 2000, 67, 2785-2793. [CrossRef]

10. Hoehle, S.I.; Pfeiffer, E.; Metzler, M. Glucuronidation of curcuminoids by human microsomal and recombinant UDP-glucuronosyltransferases. Mol. Nutr. Food Res. 2007, 51, 932-938. [CrossRef] [PubMed]

11. Prasad, S.; Tyagi, A.K.; Aggarwal, B.B. Recent developments in delivery, bioavailability, absorption and metabolism of curcumin: The golden pigment from golden spice. Cancer Res. Treat. 2014, 46, 2-18. [CrossRef] [PubMed]

12. Tsuda, T. Curcumin as a functional food-derived factor: Degradation products, metabolites, bioactivity, and future perspectives. Food Funct. 2018, 9, 705-714. [CrossRef] [PubMed]

13. Hoehle, S.I.; Pfeiffer, E.; Solyom, A.M.; Metzler, M. Metabolism of curcuminoids in tissue slices and subcellular fractions from rat liver. J. Agric. Food Chem. 2006, 54, 756-764. [CrossRef] [PubMed]

14. Pfeiffer, E.; Hoehle, S.I.; Walch, S.G.; Riess, A.; Solyom, A.M.; Metzler, M. Curcuminoids form reactive glucuronides in vitro. J. Agric. Food Chem. 2007, 55, 538-544. [CrossRef] [PubMed]

15. Huang, Y.Y.; Cao, S.J.; Zhang, Q.; Zhang, H.Y.; Fan, Y.Q.; Qiu, F.; Kang, N. Biological and pharmacological effects of hexahydrocurcumin, a metabolite of curcumin. Arch. Biochem. Biophys. 2018, 646, 31-37. [CrossRef] [PubMed] 
16. Dempe, J.S.; Scheerle, R.K.; Pfeiffer, E.; Metzler, M. Metabolism and permeability of curcumin in cultured Caco-2 cells. Mol. Nutr. Food Res. 2013, 57, 1543-1549. [CrossRef] [PubMed]

17. Metzler, M.; Pfeiffer, E.; Schulz, S.I.; Dempe, J.S. Curcumin uptake and metabolism. BioFactors 2013, 39, 14-20. [CrossRef] [PubMed]

18. Dempe, J.S.; Pfeiffer, E.; Grimm, A.S.; Metzler, M. Metabolism of curcumin and induction of mitotic catastrophe in human cancer cells. Mol. Nutr. Food Res. 2008, 52, 1074-1081. [CrossRef] [PubMed]

19. De Oliveira, M.R.; Jardim, F.R.; Setzer, W.N.; Nabavi, S.M.; Nabavi, S.F. Curcumin, mitochondrial biogenesis, and mitophagy: Exploring recent data and indicating future needs. Biotechnol. Adv. 2016, 34, 813-826. [CrossRef] [PubMed]

20. Lou, Y.; Zheng, J.; Hu, H.; Lee, J.; Zeng, S. Application of ultra-performance liquid chromatography coupled with quadrupole time-of-flight mass spectrometry to identify curcumin metabolites produced by human intestinal bacteria. J. Chromatogr. B Anal. Technol. Biomed. Life Sci. 2015, 985, 38-47. [CrossRef] [PubMed]

21. An, C.-Y.; Sun, Z.-Z.; Shen, L.; Ji, H.-F. Biotransformation of food spice curcumin by gut bacterium Bacillus megaterium DCMB-002 and its pharmacological implications. Food Nutr. Res. 2017, 61. [CrossRef]

22. Burapan, S.; Kim, M.; Han, J. Curcuminoid demethylation as an alternative metabolism by human intestinal microbiota. J. Agric. Food Chem. 2017, 65, 3306-3311. [CrossRef] [PubMed]

23. Asouri, M.; Ataee, R.; Ahmadi, A.A.; Amini, A.; Moshaei, M.R. Antioxidant and free radical scavenging activities of curcumin. Asian J. Chem. 2013, 25, 7593-7595.

24. Derochette, S.; Franck, T.; Mouithys-Mickalad, A.; Ceusters, J.; Deby-Dupont, G.; Lejeune, J.P.; Neven, P.; Serteyn, D. Curcumin and resveratrol act by different ways on NADPH oxidase activity and reactive oxygen species produced by equine neutrophils. Chem.-Biol. Interact. 2013, 206, 186-193. [CrossRef] [PubMed]

25. Zheng, Q.T.; Yang, Z.H.; Yu, L.Y.; Ren, Y.Y.; Huang, Q.X.; Liu, Q.; Ma, X.Y.; Chen, Z.K.; Wang, Z.B.; Zheng, X. Synthesis and antioxidant activity of curcumin analogs. J. Asian Nat. Prod. Res. 2017, 19, 489-503. [CrossRef] [PubMed]

26. Dikmen, M.; Kaya-Tilki, E.; Engur, S.; Ozturk, Y. Neuritogenic activity of epigallocatechin gallate and curcumin combination on rat adrenal pheochromocytoma cells. Fresenius Environ. Bull. 2017, 26, 4726-4733.

27. Tapia, E.; Sanchez-Lozada, L.G.; Garcia-Nino, W.R.; Garcia, E.; Cerecedo, A.; Garcia-Arroyo, F.E.; Osorio, H.; Arellano, A.; Cristobal-Garcia, M.; Loredo, M.L.; et al. Curcumin prevents maleate-induced nephrotoxicity: Relation to hemodynamic alterations, oxidative stress, mitochondrial oxygen consumption and activity of respiratory complex I. Free Radic. Res. 2014, 48, 1342-1354. [CrossRef] [PubMed]

28. Dai, J.; Gu, L.; Su, Y.; Wang, Q.; Zhao, Y.; Chen, X.; Deng, H.; Li, W.; Wang, G.; Li, K. Inhibition of curcumin on influenza a virus infection and influenzal pneumonia via oxidative stress, TLR2/4, p38/jnk mapk and NF-кB pathways. Int. Immunopharmacol. 2018, 54, 177-187. [CrossRef] [PubMed]

29. Dai, C.S.; Tang, S.S.; Li, D.W.; Zhao, K.N.; Xiao, X.L. Curcumin attenuates quinocetone-induced oxidative stress and genotoxicity in human hepatocyte 102 cells. Toxicol. Mech. Methods 2015, 25, 340-346. [CrossRef] [PubMed]

30. Maugeri, A.; Mazzone, M.G.; Giuliano, F.; Vinciguerra, M.; Basile, G.; Barchitta, M.; Agodi, A. Curcumin modulates DNA methyltransferase functions in a cellular model of diabetic retinopathy. Oxid. Med. Cell. Longev. 2018, 2018, 5407482. [CrossRef] [PubMed]

31. Singh, P.; Rizvi, S.I. Role of curcumin in modulating plasma PON1 arylesterase activity and susceptibility to LDL oxidation in oxidatively challenged Wistar rats. Lett. Drug Des. Discov. 2015, 12, 319-323. [CrossRef]

32. Joshi, D.; Mittal, D.K.; Shukla, S.; Srivastav, S.K.; Dixit, V.A. Curcuma longa Linn. Extract and curcumin protect CYP 2E1 enzymatic activity against mercuric chloride-induced hepatotoxicity and oxidative stress: A protective approach. Exp. Toxicol. Pathol. 2017, 69, 373-382. [CrossRef] [PubMed]

33. El-Bahr, S.M. Effect of curcumin on hepatic antioxidant enzymes activities and gene expressions in rats intoxicated with aflatoxin b1. Phytother. Res. 2015, 29, 134-140. [CrossRef] [PubMed]

34. Goc, Z.; Semla, M.; Kapusta, E.; Gren, A.; Muchacka, R.; Lukacova, J. The effect of curcumin on the activity of antioxidant enzymes in the liver, pancreas and kidneys of Swiss mice. In Proceedings of the 12th International Scientific Conference on Animal Physiology, Boretice, Czech Republic, 13-15 June 2016.

35. Altintoprak, N.; Kar, M.; Acar, M.; Berkoz, M.; Muluk, N.B.; Cingi, C. Antioxidant activities of curcumin in allergic rhinitis. Eur. Arch. Otorhinolaryngol. 2016, 273, 3765-3773. [CrossRef] [PubMed]

36. Singh, P.; Kesharwani, R.K.; Misra, K.; Rizvi, S.I. Modulation of erythrocyte plasma membrane redox system activity by curcumin. Biochem. Res. Int. 2016, 2016, 6025245. [CrossRef] [PubMed] 
37. Xu, D.P.; Li, Y.; Meng, X.; Zhou, T.; Zhou, Y.; Zheng, J.; Zhang, J.J.; Li, H.B. Natural antioxidants in foods and medicinal plants: Extraction, assessment and resources. Int. J. Mol. Sci. 2017, 18, 96. [CrossRef] [PubMed]

38. Pompella, A.; Sies, H.; Wacker, R.; Brouns, F.; Grune, T.; Biesalski, H.K.; Frank, J. The use of total antioxidant capacity as surrogate marker for food quality and its effect on health is to be discouraged. Nutrition 2014, 30, 791-793. [CrossRef] [PubMed]

39. Wang, J.; Wang, H.Y.; Zhu, R.R.; Liu, Q.; Fei, J.; Wang, S.L. Anti-inflammatory activity of curcumin-loaded solid lipid nanoparticles in IL-1 beta transgenic mice subjected to the, lipopolysaccharide-induced sepsis. Biomaterials 2015, 53, 475-483. [CrossRef] [PubMed]

40. Antoine, F.; Girard, D. Curcumin increases gelatinase activity in human neutrophils by a p38 mitogen-activated protein kinase (MAPK)-independent mechanism. J. Immunotoxicol. 2015, 12, 188-193. [CrossRef] [PubMed]

41. Li, H.Y.; Yang, M.; Li, Z.; Meng, Z. Curcumin inhibits angiotensin II-induced inflammation and proliferation of rat vascular smooth muscle cells by elevating PPAR-gamma activity and reducing oxidative stress. Int. J. Mol. Med. 2017, 39, 1307-1316. [CrossRef] [PubMed]

42. Zhang, Y.L.; Liu, Z.G.; Wu, J.Z.; Bai, B.; Chen, H.J.; Xiao, Z.X.; Chen, L.F.; Zhao, Y.J.; Lum, H.; Wang, Y.; et al. New MD2 inhibitors derived from curcumin with improved anti-inflammatory activity. Eur. J. Med. Chem. 2018, 148, 291-305. [CrossRef] [PubMed]

43. Wu, N.C.; Wang, J.J. Curcumin attenuates liver warm ischemia and reperfusion-induced combined restrictive and obstructive lung disease by reducing matrix metalloprotease 9 activity. Transplant. Proc. 2014, 46, 1135-1138. [CrossRef] [PubMed]

44. Ferreira, V.H.; Nazli, A.; Dizzell, S.E.; Mueller, K.; Kaushic, C. The anti-inflammatory activity of curcumin protects the genital mucosal epithelial barrier from disruption and blocks replication of HIV-1 and HSV-2. PLoS ONE 2015, 10, e0124903. [CrossRef] [PubMed]

45. Kloesch, B.; Gober, L.; Loebsch, S.; Vcelar, B.; Helson, L.; Steiner, G. In vitro study of a liposomal curcumin formulation (lipocurc (TM)): Toxicity and biological activity in synovial fibroblasts and macrophages. In Vivo 2016, 30, 413-419. [PubMed]

46. Esatbeyoglu, T.; Ulbrich, K.; Rehberg, C.; Rohn, S.; Rimbach, G. Thermal stability, antioxidant, and antiinflammatory activity of curcumin and its degradation product 4-vinyl guaiacol. Food Funct. 2015, 6, 887-893. [CrossRef] [PubMed]

47. Song, Z.L.; Revelo, X.; Shao, W.J.; Tian, L.L.; Zeng, K.J.; Lei, H.; Sun, H.S.; Woo, M.; Winer, D.; Jin, T. Dietary curcumin intervention targets mouse white adipose tissue inflammation and brown adipose tissue ucp1 expression. Obesity 2018, 26, 547-558. [CrossRef] [PubMed]

48. Hui-Yin, Y.; Ahmad, N.; Azmi, N.; Makmor-Bakry, M. Curcumin: The molecular mechanisms of action in inflammation and cell death during kainate-induced epileptogenesis. Indian J. Pharm. Educ. 2018, 52, $32-41$. [CrossRef]

49. Wang, J.; Kang, Y.X.; Pan, W.; Lei, W.; Feng, B.; Wang, X.J. Enhancement of anti-inflammatory activity of curcumin using phosphatidylserine-containing nanoparticles in cultured macrophages. Int. J. Mol. Sci. 2016, 17, 969. [CrossRef] [PubMed]

50. Hunter, C.J.; De Plaen, I.G. Inflammatory signaling in nec: Role of NF-kappab, cytokines and other inflammatory mediators. Pathophysiol. 2014, 21, 55-65. [CrossRef] [PubMed]

51. Kao, N.J.; Hu, J.Y.; Wu, C.S.; Kong, Z.L. Curcumin represses the activity of inhibitor-kappa b kinase in dextran sulfate sodium-induced colitis by S-nitrosylation. Int. Immunopharmacol. 2016, 38, 1-7. [CrossRef] [PubMed]

52. Dai, C.S.; Ciccotosto, G.D.; Cappai, R.; Tang, S.S.; Li, D.W.; Xie, S.L.; Xiao, X.L.; Velkov, T. Curcumin attenuates colistin-induced neurotoxicity in N2a cells via anti-inflammatory activity, suppression of oxidative stress, and apoptosis. Mol. Neurobiol. 2018, 55, 421-434. [CrossRef] [PubMed]

53. Cheng, F.; Chen, Y.H.; Zhan, Z.; Liu, Y.; Hu, P.; Ren, H.; Tang, H.D.; Peng, M.L. Curc-MPEG454, a pegylated curcumin derivative, improves anti-inflammatory and antioxidant activities: A comparative study. Inflammation 2018, 41, 579-594. [CrossRef] [PubMed]

54. Liu, W.F.; Li, Y.L.; Yue, Y.; Zhang, K.; Chen, Q.; Wang, H.Q.; Lu, Y.J.; Huang, M.T.; Zheng, X.; Du, Z.Y. Synthesis and biological evaluation of curcumin derivatives containing NSAIDs for their anti-inflammatory activity. Bioorg. Med. Chem. Lett. 2015, 25, 3044-3051. [CrossRef] [PubMed] 
55. Wang, Z.S.; Chen, L.Z.; Zhou, H.P.; Liu, X.H.; Chen, F.H. Diarylpentadienone derivatives (curcumin analogues): Synthesis and anti-inflammatory activity. Bioorg. Med. Chem. Lett. 2017, 27, 1803-1807. [CrossRef] [PubMed]

56. Yang, H.X.; Du, Z.Y.; Wang, W.C.; Song, M.Y.; Sanidad, K.; Sukamtoh, E.; Zheng, J.; Tian, L.; Xiao, H.; Liu, Z.H.; et al. Structure-activity relationship of curcumin: Role of the methoxy group in anti-inflammatory and anticolitis effects of curcumin. J. Agric. Food Chem. 2017, 65, 4509-4515. [CrossRef] [PubMed]

57. Abdollahi, E.; Momtazi, A.A.; Johnston, T.P.; Sahebkar, A. Therapeutic effects of curcumin in inflammatory and immune-mediated diseases: A nature-made jack-of-all-trades? J. Cell. Physiol. 2018, 233, 830-848. [CrossRef] [PubMed]

58. Shakeri, F.; Boskabady, M.H. Anti-inflammatory, antioxidant, and immunomodulatory effects of curcumin in ovalbumin-sensitized rat. BioFactors 2017, 43, 567-576. [CrossRef] [PubMed]

59. Han, F.; Luo, B.; Shi, R.; Han, C.; Zhang, Z.; Xiong, J.; Jiang, M.; Zhang, Z. Curcumin ameliorates rat experimental autoimmune neuritis. J. Neurosci. Res. 2014, 92, 743-750. [CrossRef] [PubMed]

60. Yang, Z.; He, C.M.; He, J.Y.; Chu, J.; Liu, H.P.; Deng, X.Y. Curcumin-mediated bone marrow mesenchymal stem cell sheets create a favorable immune microenvironment for adult full-thickness cutaneous wound healing. Stem Cell. Res. Ther. 2018, 9, 21. [CrossRef] [PubMed]

61. Afia, M.; Alshehri, M.; Alfaifi, M.; Shakor, A.B.A. Repressive effect of curcumin against 2-amino3-methylimidazo 4, 5-f quinoline induced hepato- and immunotoxicity in mice. Indian J. Exp. Biol. 2017, 55, 365-371.

62. Wang, S.; Li, H.; Zhang, M.; Yue, L.T.; Wang, C.C.; Zhang, P.; Liu, Y.; Duan, R.S. Curcumin ameliorates experimental autoimmune myasthenia gravis by diverse immune cells. Neurosci. Lett. 2016, 626, 25-34. [CrossRef] [PubMed]

63. Liu, Y.; Chen, L.Y.; Shen, Y.; Tan, T.; Xie, N.Z.; Luo, M.; Li, Z.H.; Xie, X.Y. Curcumin ameliorates ischemia-induced limb injury through immunomodulation. Med. Sci. Monit. 2016, 22, 2035-2042. [CrossRef] [PubMed]

64. Kumar, A.; Sasmal, D.; Jadav, S.S.; Sharma, N. Mechanism of immunoprotective effects of curcumin in DLM-induced thymic apoptosis and altered immune function: An in silico and in vitro study. Immunopharmacol. Immunotoxicol. 2015, 37, 488-498. [CrossRef] [PubMed]

65. Bose, S.; Panda, A.K.; Mukherjee, S.; Sa, G. Curcumin and tumor immune-editing: Resurrecting the immune system. Cell Div. 2015, 10, 6. [CrossRef] [PubMed]

66. Mahmoud, H.K.; Al-Sagheer, A.A.; Reda, F.M.; Mahgoub, S.A.; Ayyat, M.S. Dietary curcumin supplement influence on growth, immunity, antioxidant status, and resistance to aeromonas hydrophila in oreochromis niloticus. Aquaculture 2017, 475, 16-23. [CrossRef]

67. Xun, W.J.; Shi, L.G.; Zhou, H.L.; Hou, G.Y.; Cao, T.; Zhao, C.P. Effects of curcumin on growth performance, jejunal mucosal membrane integrity, morphology and immune status in weaned piglets challenged with enterotoxigenic Escherichia coli. Int. Immunopharmacol. 2015, 27, 46-52. [CrossRef] [PubMed]

68. Lee, G.; Chung, H.S.; Lee, K.; Lee, H.; Kim, M.; Bae, H. Curcumin attenuates the scurfy-induced immune disorder, a model of ipex syndrome, with inhibiting Th1/Th2/Th17 responses in mice. Phytomedicine 2017, 33, 1-6. [CrossRef] [PubMed]

69. Siegel, R.L.; Miller, K.D.; Jemal, A. Cancer statistics, 2017. CA. Cancer J. Clin. 2017, 67, 7-30. [CrossRef] [PubMed]

70. Liu, F.R.; Gao, S.; Yang, Y.X.; Zhao, X.D.; Fan, Y.M.; Ma, W.X.; Yang, D.R.; Yang, A.M.; Yu, Y. Antitumor activity of curcumin by modulation of apoptosis and autophagy in human lung cancer A549 cells through inhibiting PI3K/Akt/mTOR pathway. Oncol. Rep. 2018, 39, 1523-1531. [CrossRef] [PubMed]

71. Carroll, R.E.; Benya, R.V.; Turgeon, D.K.; Vareed, S.; Neuman, M.; Rodriguez, L.; Kakarala, M.; Carpenter, P.M.; McLaren, C.; Meyskens, F.L., Jr.; et al. Phase II a clinical trial of curcumin for the prevention of colorectal neoplasia. Cancer Prev. Res. 2011, 4, 354-364. [CrossRef] [PubMed]

72. Feng, S.Y.; Wang, Y.; Zhang, R.K.; Yang, G.W.; Liang, Z.B.; Wang, Z.W.; Zhang, G.H. Curcumin exerts its antitumor activity through regulation of miR-7/Skp2/p21 in nasopharyngeal carcinoma cells. Onco Targets Ther. 2017, 10, 2377-2388. [CrossRef] [PubMed]

73. Xi, Y.; Gao, H.; Callaghan, M.U.; Fribley, A.M.; Garshott, D.M.; Xu, Z.X.; Zeng, Q.H.; Li, Y.L. Induction of Bcl2-interacting killer, Bik, is mediated for anti-cancer activity of curcumin in human head and neck squamous cell carcinoma cells. J. Cancer 2015, 6, 327-332. [CrossRef] [PubMed] 
74. Yoysungnoen-Chintana, P.; Bhattarakosol, P.; Patumraj, S. Antitumor and antiangiogenic activities of curcumin in cervical cancer xenografts in nude mice. BioMed Res. Int. 2014, 10, 817972. [CrossRef] [PubMed]

75. Zhan, Y.Z.; Chen, Y.N.; Liu, R.; Zhang, H.; Zhang, Y.M. Potentiation of paclitaxel activity by curcumin in human breast cancer cell by modulating apoptosis and inhibiting EGFR signaling. Arch. Pharm. Res. 2014, 37, 1086-1095. [CrossRef] [PubMed]

76. Montgomery, A.; Adeyeni, T.; San, K.; Heuertz, R.M.; Ezekiel, U.R. Curcumin sensitizes silymarin to exert synergistic anticancer activity in colon cancer cells. J. Cancer 2016, 7, 1250-1257. [CrossRef] [PubMed]

77. Zhou, X.X.; Su, J.N.; Feng, S.Y.; Wang, L.X.; Yin, X.Y.; Yan, J.Z.; Wang, Z.W. Antitumor activity of curcumin is involved in down-regulation of YAP/TAZ expression in pancreatic cancer cells. Oncotarget 2016, 7, 79062-79074. [CrossRef] [PubMed]

78. Kumar, P.; Barua, C.C.; Sulakhiya, K.; Sharma, R.K. Curcumin ameliorates cisplatin-induced nephrotoxicity and potentiates its anticancer activity in SD rats: Potential role of curcumin in breast cancer chemotherapy. Front. Pharmacol. 2017, 8, 132. [CrossRef] [PubMed]

79. Goncalves, V.D.; Ortega, A.A.C.; Guimaraes, M.R.; Curylofo, F.A.; Rossa, C.; Ribeiro, D.A.; Spolidorio, L.C. Chemopreventive activity of systemically administered curcumin on oral cancer in the 4-nitroquinoline 1-oxide model. J. Cell. Biochem. 2015, 116, 787-796. [CrossRef] [PubMed]

80. Hosseini, S.; Chamani, J.; Rahimi, H.; Azmoodeh, N.; Ghasemi, F.; Abadi, P.H. An in vitro study on curcumin delivery by nano-micelles for esophageal squamous cell carcinoma (KYSE-30). Rep. Biochem. Mol. Biol. 2018, 6, 137-143. [PubMed]

81. Meena, R.; Kumar, S.; Kumar, R.; Gaharwar, U.S.; Rajamani, P. Plga-ctab curcumin nanoparticles: Fabrication, characterization and molecular basis of anticancer activity in triple negative breast cancer cell lines (MDA-MB-231 cells). Biomed. Pharmacother. 2017, 94, 944-954. [CrossRef] [PubMed]

82. Francis, A.P.; Murthy, P.B.; Devasena, T. Bis-demethoxy curcumin analog nanoparticles: Synthesis, characterization, and anticancer activity in vitro. J. Nanosci. Nanotechnol. 2014, 14, 4865-4873. [CrossRef] [PubMed]

83. Ono, M.; Higuchi, T.; Takeshima, M.; Chen, C.; Nakano, S. Differential anti-tumor activities of curcumin against Ras- and SRC-activated human adenocarcinoma cells. Biochem. Biophys. Res. Commun. 2013, 436, 186-191. [CrossRef] [PubMed]

84. Rana, C.; Piplani, H.; Vaish, V.; Nehru, B.; Sanyal, S.N. Downregulation of telomerase activity by diclofenac and curcumin is associated with cell cycle arrest and induction of apoptosis in colon cancer. Tumor Biol. 2015, 36, 5999-6010. [CrossRef] [PubMed]

85. Choudhury, D.; Ganguli, A.; Dastidar, D.G.; Acharya, B.R.; Das, A.; Chakrabarti, G. Apigenin shows synergistic anticancer activity with curcumin by binding at different sites of tubulin. Biochimie 2013, 95, 1297-1309. [CrossRef] [PubMed]

86. Gao, X.; Wang, B.L.; Wu, Q.J.; Wei, X.W.; Zheng, F.J.; Men, K.; Shi, H.S.; Huang, N.; Wei, Y.Q.; Gong, C.Y. Combined delivery and anti-cancer activity of paclitaxel and curcumin using polymeric micelles. J. Biomed. Nanotechnol. 2015, 11, 578-589. [CrossRef] [PubMed]

87. Zhang, J.M.; Li, J.J.; Shi, Z.; Yang, Y.; Xie, X.; Lee, S.M.; Wang, Y.T.; Leong, K.W.; Chen, M.W. Ph-sensitive polymeric nanoparticles for co-delivery of doxorubicin and curcumin to treat cancer via enhanced pro-apoptotic and anti-angiogenic activities. Acta Biomater. 2017, 58, 349-364. [CrossRef] [PubMed]

88. Mahmud, M.; Piwoni, A.; Filiczak, N.; Janicka, M.; Gubernator, J. Long-circulating curcumin-loaded liposome formulations with high incorporation efficiency, stability and anticancer activity towards pancreatic adenocarcinoma cell lines in vitro. PLoS ONE 2016, 11, e0167787. [CrossRef] [PubMed]

89. Ono, M.; Higuchi, T.; Takeshima, M.; Chen, C.; Nakano, S. Antiproliferative and apoptosis-inducing activity of curcumin against human gallbladder adenocarcinoma cells. Anticancer Res. 2013, 33, 1861-1866. [PubMed]

90. Sahu, B.P.; Hazarika, H.; Bharadwaj, R.; Loying, P.; Baishya, R.; Dash, S.; Das, M.K. Curcumin-docetaxel co-loaded nanosuspension for enhanced anti-breast cancer activity. Expert Opin. Drug Deliv. 2016, 13, 1065-1074. [CrossRef] [PubMed]

91. Koohpar, Z.K.; Entezari, M.; Movafagh, A.; Hashemi, M. Anticancer activity of curcumin on human breast adenocarcinoma: Role of mcl-1 gene. Iran J. Cancer Prev. 2015, 8, e2331. [CrossRef] [PubMed] 
92. Seo, J.A.; Kim, B.; Dhanasekaran, D.N.; Tsang, B.K.; Song, Y.S. Curcumin induces apoptosis by inhibiting sarco/endoplasmic reticulum $\mathrm{Ca}^{2+}$ ATPase activity in ovarian cancer cells. Cancer Lett. 2016, 371, 30-37. [CrossRef] [PubMed]

93. Lee, J.S.; Wang, T.S.; Lin, M.C.; Lin, W.W.; Yang, J.J. Inhibition of curcumin on ZAK alpha activity resultant in apoptosis and anchorage-independent growth in cancer cells. Chin. J. Physiol. 2017, 60, 267-274. [CrossRef] [PubMed]

94. He, Z.-Y.; Shi, C.-B.; Wen, H.; Li, F.-L.; Wang, B.-L.; Wang, J. Upregulation of p53 expression in patients with colorectal cancer by administration of curcumin. Cancer Investig. 2011, 29, 208-213. [CrossRef] [PubMed]

95. Yang, C.H.; Yue, J.M.; Sims, M.; Pfeffer, L.M. The curcumin analog EF24 targets NF-kappa B and miRNA-21, and has potent anticancer activity in vitro and in vivo. PLoS ONE 2013, 8, e71130. [CrossRef]

96. Zhang, W.; Bai, W.; Zhang, W. Mir-21 suppresses the anticancer activities of curcumin by targeting pten gene in human non-small cell lung cancer A549 cells. Clin. Transl. Oncol. 2014, 16, 708-713. [CrossRef] [PubMed]

97. Khan, M.N.; Haggag, Y.A.; Lane, M.E.; McCarron, P.A.; Tambuwala, M.M. Polymeric nano-encapsulation of curcumin enhances its anti-cancer activity in breast (MDA-MB231) and lung (A549) cancer cells through reduction in expression of HIF-1 alpha and nuclear p65 (Rel A). Curr. Drug Deliv. 2018, 15, 286-295. [CrossRef] [PubMed]

98. Balakrishna, A.; Kumar, M.H. Evaluation of synergetic anticancer activity of berberine and curcumin on different models of A549, Hep-G2, MCF-7, Jurkat, and K562 cell lines. BioMed Res. Int. 2015, 2015, 354614. [CrossRef] [PubMed]

99. Park, B.H.; Lim, J.E.; Jeon, H.G.; Seo, S.I.; Lee, H.M.; Choi, H.Y.; Jeon, S.S.; Jeong, B.C. Curcumin potentiates antitumor activity of cisplatin in bladder cancer cell lines via ROS-mediated activation of ERK1/2. Oncotarget 2016, 7, 63870-63886. [CrossRef] [PubMed]

100. Orr, W.S.; Denbo, J.W.; Saab, K.R.; Ng, C.Y.; Wu, J.R.; Li, K.; Garner, J.M.; Morton, C.L.; Du, Z.Y.; Pfeffer, L.M.; et al. Curcumin potentiates rhabdomyosarcoma radiosensitivity by suppressing NF-kappa B activity. PLoS ONE 2013, 8, e51309. [CrossRef] [PubMed]

101. Shakibaei, M.; Kraehe, P.; Popper, B.; Shayan, P.; Goel, A.; Buhrmann, C. Curcumin potentiates antitumor activity of 5-fluorouracil in a 3D alginate tumor microenvironment of colorectal cancer. BMC Cancer 2015, 15, 250. [CrossRef] [PubMed]

102. Zhang, P.; Lai, Z.L.; Chen, H.F.; Zhang, M.; Wang, A.; Jia, T.; Sun, W.Q.; Zhu, X.M.; Chen, X.F.; Zhao, Z.; et al. Curcumin synergizes with 5-fluorouracil by impairing AMPK/ULK1-dependent autophagy, AKT activity and enhancing apoptosis in colon cancer cells with tumor growth inhibition in xenograft mice. J. Exp. Clin. Cancer Res. 2017, 36, 190. [CrossRef] [PubMed]

103. Senft, C.; Polacin, M.; Priester, M.; Seifert, V.; Koegel, D.; Weissenberger, J. The nontoxic natural compound curcumin exerts anti-proliferative, anti-migratory, and anti-invasive properties against malignant gliomas. BMC Cancer 2010, 10, 491. [CrossRef] [PubMed]

104. Deng, Y.; Verron, E.; Rohanizadeh, R. Molecular mechanisms of anti-metastatic activity of curcumin. Anticancer Res. 2016, 36, 5639-5647. [CrossRef] [PubMed]

105. Li, S.L.; Fang, C.S.; Zhang, J.Q.; Liu, B.L.; Wei, Z.Q.; Fan, X.Q.; Sui, Z.; Tan, Q.Y. Catanionic lipid nanosystems improve pharmacokinetics and anti-lung cancer activity of curcumin. Nanomedicine 2016, 12, 1567-1579. [CrossRef] [PubMed]

106. Zhang, W.L.; Cui, T.; Liu, L.; Wu, Q.J.; Sun, L.; Li, L.; Wang, N.; Gong, C.Y. Improving anti-tumor activity of curcumin by polymeric micelles in thermosensitive hydrogel system in colorectal peritoneal carcinomatosis model. J. Biomed. Nanotechnol. 2015, 11, 1173-1182. [CrossRef] [PubMed]

107. Zheng, J.; Zhou, Y.; Li, Y.; Xu, D.P.; Li, S.; Li, H.B. Spices for prevention and treatment of cancers. Nutrients 2016, 8, 495. [CrossRef] [PubMed]

108. Zhou, Y.; Zheng, J.; Li, Y.; Xu, D.P.; Li, S.; Chen, Y.M.; Li, H.B. Natural polyphenols for prevention and treatment of cancer. Nutrients 2016, 8, 515. [CrossRef] [PubMed]

109. Abd-Allah, G.A.; El-Bakry, K.A.; Bahnasawy, M.H.; El-Khodary, E.R. Protective effects of curcumin and ginger on liver cirrhosis induced by carbon tetrachloride in rats. Int. J. Pharmacol. 2016, 12, 361-369. [CrossRef]

110. Nabavi, S.F.; Daglia, M.; Moghaddam, A.H.; Habtemariam, S.; Nabavi, S.M. Curcumin and liver disease: From chemistry to medicine. Compr. Rev. Food Sci. Food Saf. 2014, 13, 62-77. [CrossRef] 
111. Peng, X.Y.; Dai, C.S.; Liu, Q.W.; Li, J.K.; Qiu, J.R. Curcumin attenuates on carbon tetrachloride-induced acute liver injury in mice via modulation of the Nrf2/HO-1 and TGF-1/Smad3 pathway. Molecules 2018, 23, 215. [CrossRef] [PubMed]

112. Choudhury, S.T.; Das, N.; Ghosh, S.; Ghosh, D.; Chakraborty, S.; Ali, N. Vesicular (liposomal and nanoparticulated) delivery of curcumin: A comparative study on carbon tetrachloride-mediated oxidative hepatocellular damage in rat model. Int. J. Nanomed. 2016, 11, 2179-2193. [CrossRef]

113. Tung, B.T.; Hai, N.T.; Son, P.K. Hepatoprotective effect of phytosome curcumin against paracetamol-induced liver toxicity in mice. Braz. J. Pharm. Sci. 2017, 53. [CrossRef]

114. Lee, H.Y.; Kim, S.W.; Lee, G.H.; Choi, M.K.; Jung, H.W.; Kim, Y.J.; Kwon, H.J.; Chae, H.J. Turmeric extract and its active compound, curcumin, protect against chronic CCl4-induced liver damage by enhancing antioxidation. BMC Complement. Altern. Med. 2016, 16, 316. [CrossRef] [PubMed]

115. Bayindir, N.; Esrefoglu, M.; Kumas, M.; Iraz, M.; Kesgin, S.; Kilic, E. Protective effect of curcumin on cadmium-induced liver apoptosis in rats. Bezmialem Sci. 2016, 4, 99-105. [CrossRef]

116. Afrin, R.; Arumugam, S.; Soetikno, V.; Thandavarayan, R.A.; Pitchaimani, V.; Karuppagounder, V.; Sreedhar, R.; Harima, M.; Suzuki, H.; Miyashita, S.; et al. Curcumin ameliorates streptozotocin-induced liver damage through modulation of endoplasmic reticulum stress-mediated apoptosis in diabetic rats. Free Radic. Res. 2015, 49, 279-289. [CrossRef] [PubMed]

117. Granados-Castro, L.F.; Rodriguez-Rangel, D.S.; Fernandez-Rojas, B.; Leon-Contreras, J.C.; Hernandez-Pando, R.; Medina-Campos, O.N.; Eugenio-Perez, D.; Pinzon, E.; Pedraza-Chaverri, J. Curcumin prevents paracetamol-induced liver mitochondrial alterations. J. Pharm. Pharmacol. 2016, 68, 245-256. [CrossRef] [PubMed]

118. Guo, C.; Ma, J.F.; Zhong, Q.H.; Zhao, M.Y.; Hu, T.X.; Chen, T.; Qiu, L.X.; Wen, L.P. Curcumin improves alcoholic fatty liver by inhibiting fatty acid biosynthesis. Toxicol. Appl. Pharmacol. 2017, 328, 1-9. [CrossRef] [PubMed]

119. Lu, C.F.; Xu, W.X.; Zhang, F.; Shao, J.J.; Zheng, S.Z. Nrf2 knockdown disrupts the protective effect of curcumin on alcohol-induced hepatocyte necroptosis. Mol. Pharm. 2016, 13, 4043-4053. [CrossRef] [PubMed]

120. Buzzetti, E.; Pinzani, M.; Tsochatzis, E.A. The multiple-hit pathogenesis of non-alcoholic fatty liver disease (NAFLD). Metab. Clin. Exp. 2016, 65, 1038-1048. [CrossRef] [PubMed]

121. Zabihi, N.A.; Pirro, M.; Johnston, T.P.; Sahebkar, A. Is there a role for curcumin supplementation in the treatment of non-alcoholic fatty liver disease? The data suggest yes. Curr. Pharm. Des. 2017, 23, 969-982. [CrossRef] [PubMed]

122. Inzaugarat, M.E.; De Matteo, E.; Baz, P.; Lucero, D.; Garcia, C.C.; Ballerga, E.G.; Daruich, J.; Sorda, J.A.; Wald, M.R.; Chernavsky, A.C. New evidence for the therapeutic potential of curcumin to treat nonalcoholic fatty liver disease in humans. PLoS ONE 2017, 12, e0172900. [CrossRef] [PubMed]

123. Watanabe, K.; Karuppagounder, V.; Arumugam, S.; Thandavarayan, R.A.; Pitchaimani, V.; Sreedhar, R.; Afrin, R.; Harima, M.; Suzuki, H.; Suzuki, K.; et al. Pruni cortex ameliorates skin inflammation possibly through HMGB1-NF kappa B pathway in house dust mite induced atopic dermatitis NC/NGA transgenic mice. J. Clin. Biochem. Nutr. 2015, 56, 186-194. [CrossRef] [PubMed]

124. Afrin, R.; Arumugam, S.; Rahman, A.; Wahed, M.I.I.; Karuppagounder, V.; Harima, M.; Suzuki, H.; Miyashita, S.; Suzuki, K.; Yoneyama, H.; et al. Curcumin ameliorates liver damage and progression of nash in NASH-HCC mouse model possibly by modulating HMGB1-Nf-kappa B translocation. Int. Immunopharmacol. 2017, 44, 174-182. [CrossRef] [PubMed]

125. Kheradpezhouh, E.; Barritt, G.J.; Rychkov, G.Y. Curcumin inhibits activation of TRPM2 channels in rat hepatocytes. Redox Biol. 2016, 7, 1-7. [CrossRef] [PubMed]

126. Chen, N.Z.; Geng, Q.Q.; Zheng, J.B.; He, S.; Huo, X.W.; Sun, X.J. Suppression of the TGF-beta/Smad signaling pathway and inhibition of hepatic stellate cell proliferation play a role in the hepatoprotective effects of curcumin against alcohol-induced hepatic fibrosis. Int. J. Mol. Med. 2014, 34, 1110-1116. [CrossRef] [PubMed]

127. Zhang, Z.L.; Guo, Y.; Zhang, S.; Zhang, Y.; Wang, Y.Q.; Ni, W.X.; Kong, D.S.; Chen, W.J.; Zheng, S.Z. Curcumin modulates cannabinoid receptors in liver fibrosis in vivo and inhibits extracellular matrix expression in hepatic stellate cells by suppressing cannabinoid receptor type-1 in vitro. Eur. J. Pharmacol. 2013, 721, 133-140. [CrossRef] [PubMed] 
128. Zhang, F.; Zhang, Z.L.; Chen, L.; Kong, D.S.; Zhang, X.P.; Lu, C.F.; Lu, Y.; Zheng, S.Z. Curcumin attenuates angiogenesis in liver fibrosis and inhibits angiogenic properties of hepatic stellate cells. J. Cell. Mol. Med. 2014, 18, 1392-1406. [CrossRef] [PubMed]

129. Zheng, J.J.; Wu, C.Z.; Lin, Z.; Guo, Y.; Shi, L.; Dong, P.H.; Lu, Z.Q.; Gao, S.M.; Liao, Y.; Chen, B.C.; et al. Curcumin up-regulates phosphatase and tensin homologue deleted on chromosome 10 through microRNA-mediated control of DNA methylation-A novel mechanism suppressing liver fibrosis. FEBS J. 2014, 281, 88-103. [CrossRef] [PubMed]

130. Fu, X.Y.; Yang, M.F.; Cao, M.Z.; Li, D.W.; Yang, X.Y.; Sun, J.Y.; Zhang, Z.Y.; Mao, L.L.; Zhang, S.; Wang, F.Z.; et al. Strategy to suppress oxidative damage-induced neurotoxicity in PC12 cells by curcumin: The role of ROS-mediated DNA damage and the MAPK and Akt pathways. Mol. Neurobiol. 2016, 53, 369-378. [CrossRef] [PubMed]

131. Szczepanowicz, K.; Jantas, D.; Piotrowski, M.; Staron, J.; Leskiewicz, M.; Regulska, M.; Lason, W.; Warszynski, P. Encapsulation of curcumin in polyelectrolyte nanocapsules and their neuroprotective activity. Nanotechnology 2016, 27, 355101. [CrossRef] [PubMed]

132. Jin, M.L.; Park, S.Y.; Shen, Q.; Lai, Y.H.; Ou, X.M.; Mao, Z.; Lin, D.X.; Yu, Y.Y.; Zhang, W.Z. Anti-neuroinflammatory effect of curcumin on Pam3CSK4-stimulated microglial cells. Int. J. Mol. Med. 2018, 41, 521-530. [CrossRef] [PubMed]

133. Kodali, M.; Hattiangady, B.; Shetty, G.A.; Bates, A.; Shuai, B.; Shetty, A.K. Curcumin treatment leads to better cognitive and mood function in a model of Gulf War Illness with enhanced neurogenesis, and alleviation of inflammation and mitochondrial dysfunction in the hippocampus. Brain Behav. Immun. 2018, 69, 499-514. [CrossRef] [PubMed]

134. Tegenge, M.A.; Rajbhandari, L.; Shrestha, S.; Mithal, A.; Hosmane, S.; Venkatesan, A. Curcumin protects axons from degeneration in the setting of local neuroinflammation. Exp. Neurol. 2014, 253, 102-110. [CrossRef] [PubMed]

135. Liu, S.B.; Li, Q.; Zhang, M.T.; Mao-Ying, Q.L.; Hu, L.Y.; Wu, G.C.; Mi, W.L.; Wang, Y.Q. Curcumin ameliorates neuropathic pain by down-regulating spinal IL-1 beta via suppressing astroglial NALP1 inflammasome and JAK2-STAT3 signalling. Sci. Rep. 2016, 6, 28956. [CrossRef] [PubMed]

136. Zhu, X.Y.; Li, Q.; Chang, R.M.; Yang, D.; Song, Z.B.; Guo, Q.L.; Huang, C.S. Curcumin alleviates neuropathic pain by inhibiting $\mathrm{p} 300 / \mathrm{CBP}$ histone acetyltransferase activity-regulated expression of BDNF and Cox-2 in a rat model. PLoS ONE 2014, 9, e91303. [CrossRef] [PubMed]

137. Dong, W.W.; Yang, B.; Wang, L.L.; Li, B.X.; Guo, X.S.; Zhang, M.; Jiang, Z.F.; Fu, J.Q.; Pi, J.B.; Guan, D.W.; et al. Curcumin plays neuroprotective roles against traumatic brain injury partly via nrf2 signaling. Toxicol. Appl. Pharmacol. 2018, 346, 28-36. [CrossRef] [PubMed]

138. Huang, L.F.; Chen, C.W.; Zhang, X.; Li, X.; Chen, Z.P.; Yang, C.; Liang, X.L.; Zhu, G.C.; Xu, Z. Neuroprotective effect of curcumin against cerebral ischemia-reperfusion via mediating autophagy and inflammation. J. Mol. Neurosci. 2018, 64, 129-139. [CrossRef] [PubMed]

139. Hu, S.X.; Maiti, P.; Ma, Q.L.; Zuo, X.H.; Jones, M.R.; Cole, G.M.; Frautschy, S.A. Clinical development of curcumin in neurodegenerative disease. Expert Rev. Neurother. 2015, 15, 629-637. [CrossRef] [PubMed]

140. Liu, Z.J.; Li, Z.H.; Liu, L.; Tang, W.X.; Wang, Y.; Dong, M.R.; Xiao, C. Curcumin attenuates beta-amyloidinduced neuroinflammation via activation of peroxisome proliferator-activated receptor-gamma function in a rat model of Alzheimer's disease. Front. Pharmacol. 2016, 7, 261. [CrossRef] [PubMed]

141. Wang, Y.L.; Li, J.F.; Wang, Y.T.; Xu, C.Y.; Hua, L.L.; Yang, X.P.; Geng, S.; Wang, S.S.; Wang, Z.; Yin, H.L. Curcumin reduces hippocampal neuron apoptosis and JNK-3 phosphorylation in rats with A beta-induced Alzheimer's disease: Protecting spatial learning and memory. J. Neurorestoratol. 2017, 5, 117-123. [CrossRef]

142. Huang, H.C.; Zheng, B.W.; Guo, Y.; Zhao, J.; Zhao, J.Y.; Ma, X.W.; Jiang, Z.F. Antioxidative and neuroprotective effects of curcumin in an Alzheimer's disease rat model co-treated with intracerebroventricular streptozotocin and subcutaneous D-galactose. J. Alzheimers Dis. 2016, 52, 899-911. [CrossRef] [PubMed]

143. Jiang, T.F.; Zhang, Y.J.; Zhou, H.Y.; Wang, H.M.; Tian, L.P.; Liu, J.; Ding, J.Q.; Chen, S.D. Curcumin ameliorates the neurodegenerative pathology in A53T alpha-synuclein cell model of Parkinson's disease through the downregulation of mTOR/p70s6K signaling and the recovery of macroautophagy. J. Neuroimmune Pharmacol. 2013, 8, 356-369. [CrossRef] [PubMed] 
144. Sharma, N.; Nehru, B. Curcumin affords neuroprotection and inhibits alpha-synuclein aggregation in lipopolysaccharide-induced Parkinson's disease model. Inflammopharmacology 2018, 26, 349-360. [CrossRef] [PubMed]

145. Khatri, D.K.; Invekar, A.R. Neuroprotective effect of curcumin as evinced by abrogation of rotenone-induced motor deficits, oxidative and mitochondrial dysfunctions in mouse model of Parkinson's disease. Pharmacol. Biochem. Behav. 2016, 150, 39-47. [CrossRef] [PubMed]

146. Meesarapee, B.; Thampithak, A.; Jaisin, Y.; Sanvarinda, P.; Suksamrarn, A.; Tuchinda, P.; Morales, N.P.; Sanvarinda, Y. Curcumin I mediates neuroprotective effect through attenuation of quinoprotein formation, p-p38 MAPK expression, and caspase-3 activation in 6-hydroxydopamine treated SH-SY5Y cells. Phytother. Res. 2014, 28, 611-616. [CrossRef] [PubMed]

147. Abbaoui, A.; Chatoui, H.; El Hiba, O.; Gamrani, H. Neuroprotective effect of curcumin-i in copper-induced dopaminergic neurotoxicity in rats: A possible link with Parkinson's disease. Neurosci. Lett. 2017, 660, 103-108. [CrossRef] [PubMed]

148. Srivastava, P.; Yadav, R.S.; Chandravanshi, L.P.; Shukla, R.K.; Dhuriya, Y.K.; Chauhan, L.K.S.; Dwivedi, H.N.; Pant, A.B.; Khanna, V.K. Unraveling the mechanism of neuroprotection of curcumin in arsenic induced cholinergic dysfunctions in rats. Toxicol. Appl. Pharmacol. 2014, 279, 428-440. [CrossRef] [PubMed]

149. Agthong, S.; Kaewsema, A.; Charoensub, T. Curcumin ameliorates functional and structural abnormalities in cisplatin-induced neuropathy. Exp. Neurobiol. 2015, 24, 139-145. [CrossRef] [PubMed]

150. Fan, Y.L.; Li, H.C.; Zhao, W.; Peng, H.H.; Huang, F.; Jiang, W.H.; Xu, S.Y. Curcumin attenuated bupivacaine-induced neurotoxicity in SH-SY5Y cells via activation of the Akt signaling pathway. Neurochem. Res. 2016, 41, 2425-2432. [CrossRef] [PubMed]

151. Wang, R.; Tian, S.Q.; Yang, X.; Liu, J.J.; Wang, Y.H.; Sun, K. Celecoxib-induced inhibition of neurogenesis in fetal frontal cortex is attenuated by curcumin via Wnt/beta-catenin pathway. Life Sci. 2017, 185, 95-102. [CrossRef] [PubMed]

152. Carmona-Ramirez, I.; Santamaria, A.; Tobon-Velasco, J.C.; Orozco-Ibarra, M.; Gonzalez-Herrera, I.G.; Pedraza-Chaverri, J.; Maldonado, P.D. Curcumin restores Nrf2 levels and prevents quinolinic acid-induced neurotoxicity. J. Nutr. Biochem. 2013, 24, 14-24. [CrossRef] [PubMed]

153. Hernandez, M.; Wicz, S.; Corral, R.S. Cardioprotective actions of curcumin on the pathogenic NFAT/COX-2/prostaglandin E-2 pathway induced during Trypanosoma cruzi infection. Phytomedicine 2016, 23, 1392-1400. [CrossRef] [PubMed]

154. Yu, W.; Zha, W.L.; Ke, Z.Q.; Min, Q.; Li, C.R.; Sun, H.R.; Liu, C. Curcumin protects neonatal rat cardiomyocytes against high glucose-induced apoptosis via PI3K/Akt signalling pathway. J. Diabetes Res. 2016, 2016, 4158591. [CrossRef] [PubMed]

155. Kohli, S.; Chhabra, A.; Jaiswal, A.; Rustagi, Y.; Sharma, M.; Rani, V. Curcumin suppresses gelatinase B mediated norepinephrine induced stress in H9c2 cardiomyocytes. PLoS ONE 2013, 8, e76519. [CrossRef] [PubMed]

156. Manghani, C.; Gupta, A.; Tripathi, V.; Rani, V. Cardioprotective potential of curcumin against norepinephrine-induced cell death: A microscopic study. J. Microsc. 2017, 265, 232-244. [CrossRef] [PubMed]

157. Naserzadeh, P.; Mehr, S.N.; Sadabadi, Z.; Seydi, E.; Salimi, A.; Pourahmad, J. Curcumin protects mitochondria and cardiomyocytes from oxidative damage and apoptosis induced by hemiscorpius lepturus venom. Drug Res. 2018, 68, 113-120. [CrossRef] [PubMed]

158. Yang, X.B.; Jiang, H.; Shi, Y. Upregulation of heme oxygenase-1 expression by curcumin conferring protection from hydrogen peroxide-induced apoptosis in H9c2 cardiomyoblasts. Cell Biosci. 2017, 7, 523. [CrossRef] [PubMed]

159. Bai, X.J.; Hao, J.T.; Wang, J.; Zhang, W.F.; Yan, C.P.; Zhao, J.H. Curcumin inhibits cardiac hypertrophy and improves cardiovascular function via enhanced $\mathrm{Na}^{+} / \mathrm{Ca}^{2+}$ exchanger expression after transverse abdominal aortic constriction in rats. Pharmacol. Rep. 2018, 70, 60-68. [CrossRef] [PubMed]

160. Chen, R.C.; Peng, X.F.; Du, W.M.; Wu, Y.; Huang, B.; Xue, L.; Wu, Q.; Qiu, H.M.; Jiang, Q.S. Curcumin attenuates cardiomyocyte hypertrophy induced by high glucose and insulin via the PPAR gamma/Akt/NO signaling pathway. Diabetes Res. Clin. Pract. 2015, 108, 235-242. [CrossRef] [PubMed]

161. Katanasaka, Y.; Sunagawa, Y.; Hasegawa, K.; Morimoto, T. Application of curcumin to heart failure therapy by targeting transcriptional pathway in cardiomyocytes. Biol. Pharm. Bull. 2013, 36, 13-17. [CrossRef] [PubMed] 
162. Cao, Q.; Zhang, J.X.; Gao, L.; Zhang, Y.J.; Dai, M.Y.; Bao, M.W. Dickkopf-3 upregulation mediates the cardioprotective effects of curcumin on chronic heart failure. Mol. Med. Rep. 2018, 17, 7249-7257. [CrossRef] [PubMed]

163. Feng, D.; Zou, J.; Zhang, S.S.; Li, X.C.; Lui, M.Q. Hypocholesterolemic activity of curcumin is mediated by down-regulating the expression of Niemann-Pick C1-like 1 in hamsters. J. Agric. Food Chem. 2017, 65, 276-280. [CrossRef] [PubMed]

164. Meng, B.; Li, J.; Cao, H. Antioxidant and antiinflammatory activities of curcumin on diabetes mellitus and its complications. Curr. Pharm. Des. 2013, 19, 2101-2113. [PubMed]

165. Chuengsamarn, S.; Rattanamongkolgul, S.; Luechapudiporn, R.; Phisalaphong, C.; Jirawatnotai, S. Curcumin extract for prevention of type 2 diabetes. Diabetes Care 2012, 35, 2121-2127. [CrossRef] [PubMed]

166. Li, J.; Wang, P.P.; Ying, J.; Chen, Z.; Yu, S.P. Curcumin attenuates retinal vascular leakage by inhibiting calcium/calmodulin-dependent protein kinase ii activity in streptozotocin-induced diabetes. Cell. Physiol. Biochem. 2016, 39, 1196-1208. [CrossRef] [PubMed]

167. Li, J.; Wang, P.P.; Zhu, Y.X.; Chen, Z.; Shi, T.Y.; Lei, W.S.; Yu, S.P. Curcumin inhibits neuronal loss in the retina and elevates $\mathrm{Ca}^{2+} /$ calmodulin-dependent protein kinase II activity in diabetic rats. J. Ocul. Pharmacol. Ther. 2015, 31, 555-562. [CrossRef] [PubMed]

168. Wojcik, M.; Krawczyk, M.; Wojcik, P.; Cypryk, K.; Wozniak, L.A. Molecular mechanisms underlying curcumin-mediated therapeutic effects in type 2 diabetes and cancer. Oxid. Med. Cell. Longev. 2018, 2018, 9698258. [CrossRef] [PubMed]

169. Jhong, C.-H.; Riyaphan, J.; Lin, S.-H.; Chia, Y.-C.; Weng, C.-F. Screening alpha-glucosidase and alpha-amylase inhibitors from natural compounds by molecular docking in silico. BioFactors 2015, 41, 242-251. [CrossRef] [PubMed]

170. Akolade, J.O.; Oloyede, H.O.B.; Onyenekwe, P.C. Encapsulation in chitosan-based polyelectrolyte complexes enhances antidiabetic activity of curcumin. J. Funct. Foods 2017, 35, 584-594. [CrossRef]

171. Gutierres, V.O.; Campos, M.L.; Arcaro, C.A.; Assis, R.P.; Baldan-Cimatti, H.M.; Peccinini, R.G.; Paula-Gomes, S.; Kettelhut, I.C.; Baviera, A.M.; Brunetti, I.L. Curcumin pharmacokinetic and pharmacodynamic evidences in streptozotocin-diabetic rats support the antidiabetic activity to be via metabolite(s). Evid. Based Complement. Alternat. Med. 2015, 2015, 678218. [CrossRef] [PubMed]

172. Chanpoo, M.; Petchpiboonthai, H.; Panyarachun, B.; Anupunpisit, V. Effect of curcumin in the amelioration of pancreatic islets in streptozotocin-induced diabetic mice. J. Med. Assoc. Thai. 2010, 93 (Suppl. 6), S152-S159.

173. Ou, J.L.; Mizushina, Y.; Wang, S.Y.; Chuang, D.Y.; Nadar, M.; Hsu, W.L. Structure-activity relationship analysis of curcumin analogues on anti-influenza virus activity. FEBS J. 2013, 280, 5829-5840. [CrossRef] [PubMed]

174. Abdollahi, M.F.; Zandi, M.; Shokrollahi, P.; Ehsani, M. Synthesis and characterization of curcumin segmented polyurethane with induced antiplatelet activity. J. Polym. Res. 2015, 22, 179. [CrossRef]

175. Haghighizad, H.; Touhidi, A.; Pourmotabbed, A.; Moradpour, F.; Nedaei, S.E.; Pourmotabbed, T. Curcumin improves chronic stress induced potentiated seizure activity in experimental model of epilepsy. J. Neurol. Sci. Turk. 2017, 34, 76-85.

176. Mantzorou, M.; Pavlidou, E.; Vasios, G.; Tsagalioti, E.; Giaginis, C. Effects of curcumin consumption on human chronic diseases: A narrative review of the most recent clinical data. Phytother. Res. 2018, 32, 957-975. [CrossRef] [PubMed]

177. Bilia, A.R.; Bergonzi, M.C.; Isacchi, B.; Antiga, E.; Caproni, M. Curcumin nanoparticles potentiate therapeutic effectiveness of acitrein in moderate-to-severe psoriasis patients and control serum cholesterol levels. J. Pharm. Pharmacol. 2018, 70, 919-928. [CrossRef] [PubMed]

178. Greil, R.; Greil-Ressler, S.; Weiss, L.; Schonlieb, C.; Magnes, T.; Radl, B.; Bolger, G.T.; Vcelar, B.; Sordillo, P.P. A phase 1 dose-escalation study on the safety, tolerability and activity of liposomal curcumin (lipocurc((TM))) in patients with locally advanced or metastatic cancer. Cancer Chemother. Pharmacol. 2018, 82, 695-706. [CrossRef] [PubMed]

179. Jimenez-Osorio, A.S.; Garcia-Nino, W.R.; Gonzalez-Reyes, S.; Alvarez-Mejia, A.E.; Guerra-Leon, S.; Salazar-Segovia, J.; Falcon, I.; de Oca-Solano, H.M.; Madero, M.; Pedraza-Chaverri, J. The effect of dietary supplementation with curcumin on redox status and Nrf2 activation in patients with nondiabetic or diabetic proteinuric chronic kidney disease: A pilot study. J. Renal Nutr. 2016, 26, 237-244. [CrossRef] [PubMed] 
180. Amalraj, A.; Varma, K.; Jacob, J.; Divya, C.; Kunnumakkara, A.B.; Stohs, S.J.; Gopi, S. A novel highly bioavailable curcumin formulation improves symptoms and diagnostic indicators in rheumatoid arthritis patients: A randomized, double-blind, placebo-controlled, two-dose, three-arm, and parallel-group study. J. Med. Food 2017, 20, 1022-1030. [CrossRef] [PubMed]

181. Henrotin, Y.; Gharbi, M.; Dierckxsens, Y.; Priem, F.; Marty, M.; Seidel, L.; Albert, A.; Heuse, E.; Bonnet, V.; Castermans, C. Decrease of a specific biomarker of collagen degradation in osteoarthritis, Coll2-1, by treatment with highly bioavailable curcumin during an exploratory clinical trial. BMC Complement. Altern. Med. 2014, 14, 159. [CrossRef] [PubMed]

182. Antiga, E.; Bonciolini, V.; Volpi, W.; Del Bianco, E.; Caproni, M. Oral curcumin (Meriva) is effective as an adjuvant treatment and is able to reduce IL-22 serum levels in patients with psoriasis vulgaris. BioMed Res. Int. 2015, 2015, 283634. [CrossRef] [PubMed]

183. Abdolahi, M.; Sarraf, P.; Javanbakht, M.H.; Honarvar, N.M.; Hatami, M.; Soveyd, N.; Tafakhori, A.; Sedighiyan, M.; Djalali, M.; Jafarieh, A.; et al. A novel combination of omega-3 fatty acids and nano-curcumin modulates interleukin-6 gene expression and high sensitivity c-reactive protein serum levels in patients with migraine: A randomized clinical trial study. CNS Neurol. Disord. Drug Targets 2018, 17, 430-438. [CrossRef] [PubMed]

184. Kuriakose, M.A.; Ramdas, K.; Dey, B.; Iyer, S.; Rajan, G.; Elango, K.K.; Suresh, A.; Ravindran, D.; Kumar, R.R.; Prathiba, R.; et al. A randomized double-blind placebo-controlled phase iib trial of curcumin in oral leukoplakia. Cancer Prev. Res. 2016, 9, 683-691. [CrossRef] [PubMed]

185. Duetzmann, S.; Schiborr, C.; Kocher, A.; Pilatus, U.; Hattingen, E.; Weissenberger, J.; Gessler, F.; Quick-Weller, J.; Franz, K.; Seifert, V.; et al. Intratumoral concentrations and effects of orally administered micellar curcuminoids in glioblastoma patients. Nutr. Cancer 2016, 68, 943-948. [CrossRef] [PubMed]

186. Funamoto, M.; Sunagawa, Y.; Katanasaka, Y.; Miyazaki, Y.; Imaizumi, A.; Kakeya, H.; Yamakage, H.; Satoh-Asahara, N.; Komiyama, M.; Wada, H.; et al. Highly absorptive curcumin reduces serum atherosclerotic low-density lipoprotein levels in patients with mild copd. Int. J. Chron. Obstruct. Pulmon. Dis. 2016, 11, 2029-2034. [CrossRef] [PubMed]

187. Yang, Y.S.; Su, Y.F.; Yang, H.W.; Lee, Y.H.; Chou, J.I.; Ueng, K.C. Lipid-lowering effects of curcumin in patients with metabolic syndrome: A randomized, double-blind, placebo-controlled trial. Phytother. Res. 2014, 28, 1770-1777. [CrossRef] [PubMed]

188. Chuengsamarn, S.; Rattanamongkolgul, S.; Phonrat, B.; Tungtrongchitr, R.; Jirawatnotai, S. Reduction of atherogenic risk in patients with type 2 diabetes by curcuminoid extract: A randomized controlled trial. J. Nutr. Biochem. 2014, 25, 144-150. [CrossRef] [PubMed]

189. Mirzabeigi, P.; Mohammadpour, A.H.; Salarifar, M.; Gholami, K.; Mojtahedzadeh, M.; Javadi, M.R. The effect of curcumin on some of traditional and non-traditional cardiovascular risk factors: A pilot randomized, double-blind, placebo-controlled trial. Iran. J. Pharm. Res. 2015, 14, 479-486. [PubMed]

190. Neerati, P.; Devde, R.; Gangi, A.K. Evaluation of the effect of curcumin capsules on glyburide therapy in patients with type-2 diabetes mellitus. Phytother. Res. 2014, 28, 1796-1800. [CrossRef] [PubMed]

191. Rahimi, H.R.; Mohammadpour, A.H.; Dastani, M.; Jaafari, M.R.; Abnous, K.; Mobarhan, M.G.; Oskuee, R.K. The effect of nano-curcumin on HBA1C, fasting blood glucose, and lipid profile in diabetic subjects: A randomized clinical trial. Avicenna J. Phytomed. 2016, 6, 567-577. [PubMed]

192. Kunati, S.R.; Yang, S.M.; William, B.M.; Xu, Y. An LC-MS/MS method for simultaneous determination of curcumin, curcumin glucuronide and curcumin sulfate in a phase II clinical trial. J. Pharm. Biomed. Anal. 2018, 156, 189-198. [CrossRef] [PubMed]

193. Adahoun, M.A.; Al-Akhras, M.A.H.; Jaafar, M.S.; Bououdina, M. Enhanced anti-cancer and antimicrobial activities of curcumin nanoparticles. Artif. Cells Nanomed. Biotechnol. 2017, 45, 98-107. [CrossRef] [PubMed]

194. Bai, F.; Diao, J.J.; Wang, Y.; Sun, S.X.; Zhang, H.M.; Liu, Y.Y.; Wang, Y.Q.; Cao, J. A new water-soluble nanomicelle formed through self-assembly of pectin-curcumin conjugates: Preparation, characterization, and anticancer activity evaluation. J. Agric. Food Chem. 2017, 65, 6840-6847. [CrossRef] [PubMed]

195. Khayyal, M.T.; El-Hazek, R.M.; El-Sabbagh, W.A.; Frank, J.; Behnam, D.; Abdel-Tawab, M. Micellar solubilisation enhances the antiinflammatory activities of curcumin and boswellic acids in rats with adjuvant-induced arthritis. Nutrition 2018, 54, 189-196. [CrossRef] [PubMed] 
196. Akbar, M.U.; Zia, K.M.; Nazir, A.; Iqbal, J.; Ejaz, S.A.; Akash, M.S.H. Pluronic-based mixed polymeric micelles enhance the therapeutic potential of curcumin. AAPS PharmSciTech 2018, 19, 2719-2739. [CrossRef] [PubMed]

197. Schiborr, C.; Kocher, A.; Behnam, D.; Jandasek, J.; Toelstede, S.; Frank, J. The oral bioavailability of curcumin from micronized powder and liquid micelles is significantly increased in healthy humans and differs between sexes. Mol. Nutr. Food Res. 2014, 58, 516-527. [CrossRef] [PubMed]

198. Kocher, A.; Bohnert, L.; Schiborr, C.; Frank, J. Highly bioavailable micellar curcuminoids accumulate in blood, are safe and do not reduce blood lipids and inflammation markers in moderately hyperlipidemic individuals. Mol. Nutr. Food Res. 2016, 60, 1555-1563. [CrossRef] [PubMed]

199. Li, X.; Chen, T.; Xu, L.; Zhang, Z.; Li, L.; Chen, H. Preparation of curcumin micelles and the in vitro and in vivo evaluation for cancer therapy. J. Biomed. Nanotechnol. 2014, 10, 1458-1468. [CrossRef] [PubMed]

200. Hagl, S.; Kocher, A.; Schiborr, C.; Kolesova, N.; Frank, J.; Eckert, G.P. Curcumin micelles improve mitochondrial function in neuronal PC12 cells and brains of nmri mice-impact on bioavailability. Neurochem. Int. 2015, 89, 234-242. [CrossRef] [PubMed]

201. Baker, M. Deceptive curcumin offers cautionary tale for chemists. Nature 2017, 541, 144-145. [CrossRef] [PubMed]

202. Bahadori, F.; Demiray, M. A realistic view on "the essential medicinal chemistry of curcumin". ACS Med. Chem. Lett. 2017, 8, 893-896. [CrossRef] [PubMed]

203. Heger, M. Drug screening: Don't discount all curcumin trial data. Nature 2017, 543, 40. [CrossRef] [PubMed]

204. Jin, T.R.; Song, Z.L.; Weng, J.P.; Fantus, I.G. Curcumin and other dietary polyphenols: Potential mechanisms of metabolic actions and therapy for diabetes and obesity. Am. J. Physiol. Endocrinol. Metab. 2018, 314, E201-E205. [CrossRef] [PubMed]

(C) 2018 by the authors. Licensee MDPI, Basel, Switzerland. This article is an open access article distributed under the terms and conditions of the Creative Commons Attribution (CC BY) license (http://creativecommons.org/licenses/by/4.0/). 